\title{
Okul öncesi öğretmen ve öğretmen adaylarının aile katılımına yönelik öz-yeterlik inançlarının incelenmesi: Denizli ili örneği *
}

\section{Investigation of self-efficacy beliefs for family participation of preschool teacher and teacher candidates: Example of Denizli}

\author{
Makale Geçmişi \\ Geliş : 5 May1s 2020 \\ Düzeltme : 6 Haziran 2020 \\ Kabul : 10 Haziran 2020
}

Makale Türü

Arastırma Makalesi

\author{
Dilara Nur Başkan ${ }^{1}$, Ali Yiğit Kutluca ${ }^{2}$
}

\begin{abstract}
Öz: Bu araştırmanın amacı okul öncesi öğretmen ve öğretmen adaylarının aile katılımına yönelik özyeterlik inançlarını incelemektir. Bununla birlikte okul öncesi öğretmenlerinin ve öğretmen adaylarının aile katılımına yönelik bakış açıları arasındaki farklılıklar ve benzerlikler tespit edilmeye çalışılmıstır. $\mathrm{Bu}$ araştırma, 2019-2020 eğitim-öğretim y1lı güz döneminde Pamukkale Üniversitesinde öğrenim gören 57, son sınıf okul öncesi ögretmen adayı ve Denizli ili, Pamukkale ilçesinde bulunan okul öncesi eğitim kurumlarında görev alan 55 okul öncesi öğretmeninin katılımı ile gerçekleştirilmiştir ve araştırmada karma yöntem kullanılmıştır. Veriler katılımcılara Aile Katılımı Öz-Yeterliği Değerlendirme Ölçeği ve yarı yapılandırlmış görüşme soruları ile elde edilmiştir. Çalışmada ulaşılan nicel veriler SPSS paket programındaki uygun testler ile analiz edilirken nitel veriler ise tümevarımsal içerik analizi ve sürekli karșılaştırma yöntemi ile analiz edilmiştir. Değerlendirmeler sonucunda aile katılımına yönelik öz-yeterlik inancı açısından öğretmenler lehine anlamlı farklılık tespit edilmiştir. Okul öncesi öğretmen ve öğretmen adaylarının aile katılımı ile ilgili benzer kavramlaştırmalar yaptıkları ortaya çıkmıştır.

Anahtar Kelimeler: Aile katılımı, Öz-yeterlik, Okul öncesi eğitim, Öğretmen adayı, Okul öncesi öğretmeni

Abstract: This study aimed to investigate the self-efficacy beliefs of preschool teachers and teacher candidates regarding family engagement. Furthermore, the differences and similarities between the views of preschool teachers and teacher candidates on family engagement were explored. The study was conducted in the fall term of the 2019-2020 academic year with 57 senior preschool teacher candidates studying in Pamukkale University and 55 preschool teachers working in preschools in Pamukkale district, and mixed method was used. Data was obtained by applying the Family Engagement SelfEfficacy Assessment Scale and asking semi-structured interview questions. In this study, quantitative data was analyzed with the tests in SPSS package software, while qualitative data was analyzed using inductive content analysis and constant comparison method. The assessments demonstrated a significant difference in favor of teachers with regard to self-efficacy beliefs on family engagement. It was revealed that preschool teachers and teacher candidates had similar conceptualizations regarding family engagement.
\end{abstract}

Keywords: Family engagement, Self-efficacy, Preschool education, Preschool teacher candidate, Preschool teachers,

Başlıca Yazar: Dilara Nur Başkan

* Bu makale, Dilara Nur Başkan'ın Yükesek Lisans tęinin bir bölümü olarak sunulmustur.

1 İstanbul Aydın Üniversitesi, Lisansüstü Eğitim Enstitüsü, Temel Eğitim Bölümü, d.nur_96@hotmail.com, ORCID: https://orcid.org/0000-0002-8069-5986

2 İstanbul Aydın Üniversitesi, Eğitim Fakültesi, Temel Eğitim Bölümü, alikutluca@aydin.edu.tr, ORCID: https://orcid.org/0000-0002-1341-3432 


\section{SUMMARY}

\section{Introduction}

Children's education starts from birth in the house and parents are one of the first role models. In early childhood period, however, they are expected to take their teachers as another role model. Therefore, communication and collaboration between teachers and parents are important. Family engagement is a multidimensional exchange of information between parents and teachers that happens through collaboration, seeks to support the children's development and aims to lead to positive outcomes in children's future academic lives in order to instill in them a sense of trust and belonging (Dönmez and Ramazan, 2017). Therefore, the professional self-efficacy of teachers should be suited to manage the family engagement process actively throughout the children's education (Gökyer, 2017). The higher the selfefficacy beliefs of teachers are in this process, the more actively they will support family engagement and participate in activities with families. For teachers to have strong self-efficacy beliefs in their professional lives, they must receive a preservice training in a well-equipped setting (Krizman, 2013). A significant relationship is present between preservice training and a teacher's self-efficacy. Trainings should support teacher candidates in terms of liking the profession, self-confidence and self-efficacy. If teacher candidates start the profession when they feel self-efficacious, they can develop positive relationships and collaborations with families (Skaalvik and Skaalvik, 2010).

\section{Method}

This is a mixed-methods type study containing both qualitative and quantitative research designs. In obtaining data as part of the study, the explanatory mixed-method, which is a type of mixed methods, was selected as the study design. For the quantitative dimension, 55 preschool teachers working in Pamukkale district of Denizli and 57 senior-year teacher candidates studying in the Faculty of Education of Pamukkale University were included in the study group. For the qualitative dimension, the study group was determined according to the scores from the Family Engagement Self-Efficacy Assessment Scale applied to two different participant groups in the quantitative dimension. Means and standard deviations of preschool teachers and preschool teacher candidates from the scale were calculated, lower and upper groups were determined and a study group containing $10 \%$ of the participants were assigned for the qualitative dimension of the study. Thus, six preschool teachers and six preschool teacher candidates were asked to answer the semi-structured interview questions. As a result, the researcher formulated the semi-structure interview questions in accordance with the study aim. To develop the interview questions and ensure the internal consistency and external control of the questions, the researcher sought the opinions of two lecturers with an expertise in preschool education. So as to determine whether the semi-structured interview questions organized as per expert opinions were clear and understandable and to what extent the study would serve its purpose, the researcher conducted a pilot study in which a preschool teacher candidate and a preschool teacher were interviewed. The trustworthiness of the study was established through such criteria as 
credibility, transferability, dependability and conformability. In qualitative data, on the other hand, interceder reliability was established, data quality was supported and expert opinion was sought to ensure the credibility of data.

\section{Results}

Results from quantitative data analyses demonstrated that no significant difference was present in the selfefficacy beliefs of preschool teachers and teacher candidates on family engagement in terms of seniority, age and receiving family engagement training. On the other hand, a significant difference was detected in favor of preschool teachers with regard to self-efficacy beliefs on family engagement. However, qualitative data analysis results indicated that preschool teachers and teacher candidates had similar conceptualizations regarding family engagement. According to this, the participants mentioned social interaction, familial barriers and quality of preservice training.

\section{Conclusion and Discussion}

According to the study results, there was no significant difference in the self-efficacy beliefs of preschool teachers and teacher candidates on family engagement in terms of seniority, age and receiving family engagement training. However, a significant difference was detected between self-efficacy beliefs of preschool teachers and teacher candidates on family engagement. The self-efficacy scores of teachers and teacher candidates did not cause a marked difference between their conceptualizations regarding family engagement. As a result of the qualitative data analysis, it was observed that teachers and teacher candidates had similar conceptualizations regarding family engagement. They referred to social interaction, familial barriers and quality of preservice training and increased quality of a child's learning process as a result of family engagement. A study by Anthony (2008) reported that misunderstandings between teachers and families due to a lack of communication resulted in the failure of families to show sufficient interest in school. In line with this result, it is considered that family engagement activities during preschool years will lay a bridge between teachers and families and increase their communication, ensure social interaction and that families will be more experienced in primary school period thanks to these activities. In the present study, it was found out that an effective undergraduate education received by teacher candidates would positively improve their self-efficacy beliefs on family engagement when they begin their careers. In the light of these data, further studies can be conducted to address the possible ways of increasing the quality of family engagement processes. These may include studies to improve the barrier perceptions, self-efficacy beliefs and process management capabilities of teachers and teacher candidates regarding family engagement as well as qualitative studies to set forth the roles of teachers in activities for family engagement. More studies to contribute to increasing the social interaction with families can be performed to enhance the quality of education. Emphasis can be placed on activities to increase family engagement in order to further support the developmental areas of students. Teacher candidates can be further encouraged and supported to engage in activities for family engagement during their internship. Activities for family engagements can 
be integrated into various courses in undergraduate and graduate programs and thus, the views of teacher candidates on family engagement can be improved.

\section{GİRİ̧̧}

Çocuğun ilk rol modelleri arasında anne ve babası yer almaktadır. Çocuk, erken çocukluk dönemine girdiği sırada ise bir diğer rol model olarak öğretmenini örnek alması beklenmektedir. Bu sebeple öğretmen ve ebeveyn arasındaki iletişim ve iş birliğinin önemli olduğu düşünülmektedir. Kuvvetli bir iş birliği ebeveynlerinde çocuklarının eğitimini, öğrendiklerini, gelişimini devamlı olarak takip edebilmesini sağlayacaktır. Aynı zamanda öğretmenin de iş yükünü azaltarak çocuklara vermiş olduğu eğitimde daha verimli olabilmesi adına katkıda bulunacaktır. Aile katılımı, ailelerin çocuklarının eğitimi ile ilgili bilgi ve becerilerini arttırmaları ile yeteneklerini keşfetmelerini kapsamaktadır. Daha sonra da eğitim sürecinde bu yeteneklerini kullanarak çocuklarına yararlı olabilmelerini sağlamaktadır (Morrison, Storey ve Zhang, 2015). Aile katılımının gerçekleştirilmesi, öğretmen ve ailelerin iletişimini arttırıp ortak hareket etmelerini kolaylaştırdığı gibi çocuk içinde bu süreç oldukça önemlidir. Öncelikle aile katılımı çocuğun sosyal duygusal anlamda gelişimine olumlu yönde katkı sağlar. Çocuğun aile ile geçirebileceği zamanı artırır ve eğitiminde tutarsız davranışlar ile karşılaşma olasıllğı en aza indirgenir. Aileler çocuğunun okulda almış olduğu eğitimi takip edebildikleri için evde de gelişimini aynı şekilde destekleyebilirler. Çocuk okulda görmüş olduğunu evde de devam ettirebilirse öğrenmesi kalıcı olacaktır. Kalıcı öğrenmeler çocuğun davranışlarını şekillendirecek ve gelişim tüm alanları ile desteklenecektir (Yaşar-Ekici, 2017).

Ailelerin okul öncesi eğitimi almakta olan çocuklarının eğitimiyle ilgilenmeleri, eğitimlerine katkıda bulunmaları, aile katılımını gerçekleştirerek bu süreçte aktif rol almaları, sadece çocuğun gelişimini değil, ailenin gelişimini de önemli düzeyde etkilemekte ve olumlu yönde bir katkıda bulunmaktadır (Biber, 2018). Aile katılımı çocukların birçok gelişim alanını desteklediği gibi ailelere de çeşitli yararlar sağlamaktadır. İlk olarak ailelerin çocuklarını tanımalarına yardımcı olur. Ebeveynler aile katılımı ile çocuklarının gelişimini izleyebilirler. Bu kapsamda aileler öğrenme sürecinde çocuklarını destekleyici bilgi ve becerileri kazanırlar. Okul öncesi eğitimde aile katılımı ile çocuğun eğitiminin devamlı ve bütüncül olması sağlanmaktadır. Aynı zamanda ailelerin desteği ile öğretmenin kendi programını uygulaması da kolaylaşır ve bu durumda beraberinde başarıyı artırır (Ateş, 2015).

Okul öncesi eğitim kurumlarında okul öncesi öğretmeni ve aileler arasında sosyal bir birliktelik kurulmalı böylelikle de ortak paydada bir iş birliği sağlanmalıdır (Latipov, Bykova ve Zhigalova, 2016). Çocuklar bu iş birliği sayesinde yaratıcı düşünme becerilerini geliştirecek, başkalarına yardım etme ve okula devam etmenin önemi hakkında çok sayıda olumlu tutum ve davranışı öğrenme 
fırsatı kazanacaklardır (Erdoğan ve Demirkasımoğlu, 2010). Okul öncesi eğitimde aile katılımını başlatabilmek ve devamlılı̆̆ını sağlayabilmekte eğitimci önemli bir rol oynamaktadır. Bu süreçte öğretmenin kendine güvenmesi, sürece hâkim olması, neler yapması gerektiğini bilerek ilerlemesi katılımın devamlılı̆̆ını arttırmaktadır. Öğretmenlerin nitelikli olabilmeleri ve sorumluluklarını yerine getirebilmeleri için bütün davranışları üst düzeyde kazanmaları gerekmektedir. Bu durum da hizmet öncesinde alacakları eğitim ile doğrudan ilişkilidir (Gürbüztürk ve Çalış, 2019).

Ailenin eğitime dahil edilmesi ve okul aile iş birliğinin sağlanması için en etkili yollardan birisi de öğretmen eğitiminden geçmektedir. Fakat literatürde öğretmenlerin ve öğretmen adaylarının aile katılımı ile ilgili yetiştirilmeleri için yeterince program bulunmadığı görülmektedir (Yavuz-Güler, 2014). Öğretmen adaylarının çoğunluğu eğitim hayatlarında aile katılımı ile ilgili yeterli bilgi düzeyine ulaşmadan ve tecrübe etme şansı yakalayamadan meslek hayatlarına başlamaktadırlar. Öğretmenlerde bu sebeple süreç konusunda kendilerine güven duymakta zorlanmaktadırlar. Öğretmenin yeterli bilgi ve deneyime sahip olmaması aileyi de sürece nasıl dahil edeceği konusunda yetersiz kalmasına sebep olmaktadır. Ailenin de sergilemiş olduğu olumsuz tutumlar aile katılımının önündeki engelleri giderek arttırmaktadır. Kendine güvenen öğretmen aile katılımının önündeki engelleri aşmak içinde çabalayacaktır. Bu bağlamda öğretmenlerin iyi bir eğitim almış olması gerekmektedir fakat bununla birlikte görev ve sorumluluklarını yerine getirebilme noktasında kendilerine olan inançları da tam olmalıdır (Ay, 2007). Etkili öğretmen uygulamaları ve çocukların başarılı bir performans gösterebilmeleri öğretmen öz-yeterliği ile pozitif ilişkilidir (Guo, Justice, Sawyer ve Tompkins, 2011). Diğer yandan Krizman, (2013) araştırması kapsamında öz-yeterlik inancı yüksek olan öğretmenlerin aile katılımı çalışmalarına daha fazla yer verdiğini saptamıştır. Bunun sebebi olarak da öz-yeterliği yüksek olan öğretmenlerin eğitimi bütün olarak ele almaları gösterilebilir.

\section{Araştırmanın Önemi}

Okul öncesi dönem, çocuk için öğrenmelerin hızla geliştiği ve şekillendiği bir dönemdir. Bu süreçte çocukların almış olduğu eğitimin verimli ve kaliteli bir şekilde ilerleyebilmesi için öğretmenin, bilgi birikimine güvenebilmesi ayrıca mesleğini icra edebilmek için gerekli öz-yeterlik inancını kazanmış olması gerekmektedir (Koç, 2015). Yüksek öz yeterliğe sahip öğretmenler aile katılımı sürecini yönetme de başarılı olabilirler. Garcia, (2004) öğretmenlerin aile katılımına ilişkin öz-yeterlik inançlarının, aile katılımında büyük etkisi olduğunu belirtmiştir. Öz-yeterlik inancı yüksek öğretmenlerin yetişebilmesi için ise hizmet öncesi eğitimin kaliteli ve nitelikli olması gerekmektedir (Şenol-Ulu, 2012). Bu nedenle araştırma okul öncesi öğretmen ve öğretmen adaylarının aile katılımına yönelik öz-yeterlik inançlarının belirlenmesi, hizmet öncesi eğitim veren kurumlara ve 
öğretmenlere aile katılımı ile ilgili yön vermesi açısından önemli görülmektedir. Bu önem doğrultusunda mevcut ulusal literatür taranarak araştırmaların durumu tespit edilmeye çalış1lmıştır.

Alan yazın taraması kapsamında aile katılımına yönelik okul öncesi öğretmenleri ve öğretmen adayları ile ilgili yapılan çalışmalara rastlanılmıstır (Örn; Çetinkaya, 2017; Yakıcı, 2018). Bu çalışmalar ağırlıklı olarak öğretmen ve ebeveynler ile gerçekleştirilmiştir. Alan yazın taramasında özyeterlik alanında gerçekleştirilen çalışmalar ise ağırlıklı olarak okul öncesi öğretmen ve öğretmen adaylarının öz-yeterlik inançları üzerine gerçekleştirilen çalışmalardır (Örn; Şenol-Ulu, 2012; Gömleksiz ve Serhatoğlu, 2013). Ayrıca matematik eğitimi, fen eğitimi gibi belirli alanlara yönelik Öz-yeterlik inançlarını inceleyen çalışmalar da mevcuttur (Örn; Bulut-Üner, 2018; Büyükyıldırım, 2018). Öz-yeterlik ile ilgili gerçekleştirilen araştırmalarda da çalışma grubu olarak çoğunlukta öğretmen ve öğretmen adayları tekil olacak şekilde araştırmalar mevcuttur.

Literatür taraması kapsamında aile katılımı ve öz-yeterlik ile ilgili gerçekleştirilen çalışmalar incelenmiştir. Fakat ikisinin birlikte yer aldığ1 çalışmalar yok denecek kadar azdır (Örn; Ateş, 2015; Alaçam, 2015; Biber, 2018). İncelenen bu araştırmalarda çalışma grubu olarak iki araştırmada öğretmen adayları ile çalışılırken diğer çalışma ise öğretmenler ile gerçekleştirilmiştir. Aile katılımı ve öz-yeterlik konuları kapsamında okul öncesi öğretmen ve öğretmen adaylarının bir arada yer aldığı çalışmalar yok denecek kadar azdır. İlgili bağlamda uluslararası çalışmalar incelendiğinde ise aynı ulusal çalışmalarda görüldüğ̈̈ üzere sınırlılık mevcuttur. Bazı çalışmalarda öğretmen adaylarının aile katılımına yönelik inançları incelenirken (Baum ve McMurray-Schwarz, 2004) bazı çalışmalarda ise öğretmenlerin sanat öğretimi konusundaki öz-yeterlikleri incelenmiştir (Garvis ve Pendergast, 2011).

Öğretmen öz-yeterlik inançlarının önemli görülmesine rağmen literatürde daha çok aile öz-yeterlik inançları ve aile katılımı üzerine çalışmalara rastlanmıştır (Alaçam, 2015). Elde edilen bu veriler 1şığında alandaki sınırlı sayıdaki çalışmalardan dolayı gerçekleştirilen çalışmanın örneklem grubu açısından önemli olduğu düşünülmektedir. Diğer yandan gerçekleştirilen çalışmalarda ağırlıklı olarak nicel yöntem tercih edilmiştir (Örn; Biber, 2018; Bulut-Üner, 2018). Fakat nitel (Büyükyıldırım, 2018) veya karma yöntem (Ateş, 2015) aracıllğıyla gerçekleştirilen çalışmalar yok denecek kadar az sayıdadır. Tüm bu rasyoneller ışığında literatürde karma yöntem tercih edilerek öğretmen ve öğretmen adaylarının aile katılımına yönelik öz-yeterlik inançlarını inceleyen bir çalışmaya rastlanılmamıştır. Bu bağlamda araştırmanın çalışma yöntemi, çalışma grubu ve konu başlığı olarak literatüre katkı sağlayacağı düşünülmektedir. 
Dolayısıyla belirtilen tüm bu rasyoneller ışığında bu araştırmanın temel amacı; okul öncesi öğretmen ve öğretmen adaylarının aile katılımına yönelik öz-yeterlik inançlarının karşılaştırılmalı olarak incelenmesidir. Araştırmanın ikincil amacı ise okul öncesi öğretmen ve öğretmen adaylarının aile katılımına yönelik öz-yeterlik inançlarının üzerinde etkili olduğu düşünülen değişkenleri belirlemektir. Farklı bir çalışma olmasının yanında okul öncesi öğretmen ve öğretmen adaylarının akademik anlamda kendilerini geliştirmelerine teşvik etmesi ve eksiklerin fark edilerek eğitimde niteliğin arttırılmasına katkı sağlaması açısından yapılan çalısmanın sonucu önem arz etmekte ve bu bağlamda araştırma problemlerini oluşturmaktadır. Bu doğrultuda aşağıdaki araştırma sorularına yanıt aranmiştır.

1. Okul öncesi öğretmenlerinin aile katılımına yönelik öz-yeterlik inançları; kıdem, yaş ve aile katılımı ile ilgili eğitim alıp almadıklarına göre anlamı bir şekilde farklılaşmakta mıdır?

2. Okul öncesi öğretmen adaylarının aile katılımına yönelik öz-yeterlik inançları; yaş ve aile katılımı ile ilgili eğitim alıp almadıklarına göre anlamlı bir şekilde farklılaşmakta mıdır?

3. Okul öncesi öğretmen ve öğretmen adaylarının aile katılımına yönelik öz-yeterlik inançları arasında anlamlı bir farklılık var mıdır?

4. Okul öncesi öğretmen ve öğretmen adaylarının aile katılımına yönelik öz-yeterlik inançlarını ne tür faktörler etkiler?

\section{YÖNTEM}

Okul öncesi öğretmen ve öğretmen adaylarının aile katılımına yönelik öz-yeterlik inançlarını incelenmesi amaçlanan bu çalışmada, nicel ve nitel araştırma desenlerini birlikte barındıran karma yöntem tercih edilmiştir. Nicel ve nitel yöntemlerin bir arada tercih edilmesi ile her iki yönteminde avantajlarından yararlanılarak elde edilen olgular daha detaylı ve kapsamlı bir şekilde açılanır (Creswell, Shope, Plano-Clark ve Green, 2006). Araştırmanın bu aşamasında elde edilen nicel ve nitel verilerin detaylandırılmasında Giannakaki (2005) tarafindan belirtilen tamamlayıcılık ilkesi dikkate alınmıştır.

\section{Çalışma Grubu}

Araştırmanın nicel boyutu için çalışma grubunda Denizli ili Pamukkale ilçesinde görev yapmakta olan 55 okul öncesi öğretmeni ve Pamukkale Üniversitesi Eğitim Fakültesi 4. Sınıf 57 okul öncesi öğretmen adayı yer almaktadır. Nitel boyut için çalışma grubu ise çalışmanın nicel boyutunda yer alan iki farklı katılımcı gruplarına uygulanan Aile Katılımı Öz-Yeterliği Değerlendirme Ölçeğinden 
elde edilen puanlara göre belirlenmiştir. Okul öncesi öğretmen ve öğretmen adaylarının uygulanan ölçek kapsamında elde ettikleri puanlara göre alt ve üst grup belirlenmiş ve katılımcı grubun \%10’u olacak şekilde araştırmanın nitel boyutu için çalışma grubu belirlenmiştir. Katılımcılar ile yar1yapılandırılmış görüşmeler gerçekleştirilmiştir. Alt grupları belirlemek için amaçlı örnekleme yöntemlerinden aykır durum örneklemesi kullanılmıştır.

Tablo 1. Yarı yapılandırılmış görüşme yapılan öğretmen ve öğretmen adaylarına ait ölçek puanları

\begin{tabular}{ccc}
\hline Gruplar & Ö̆ğretmen Aday1 & AKÖYD Ölçeği Puanlar1 \\
\hline \multirow{2}{*}{ Üst Grup } & Aü & 64 \\
& $\mathrm{Bü}$ & 65 \\
& $\mathrm{Cü}$ & 66 \\
\hline \multirow{2}{*}{ Alt Grup } & $\mathrm{Aa}$ & 22 \\
& $\mathrm{Ba}$ & 27 \\
& $\mathrm{Ca}$ & 32 \\
\hline \multirow{2}{*}{ Gruplar } & Öğretmen & AKÖYD Ölçeği Puanlar1 \\
\hline \multirow{2}{*}{ Üst Grup } & $\mathrm{Aü}$ & 64 \\
& $\mathrm{Bü}$ & 66 \\
\hline \multirow{2}{*}{ Alt Grup } & $\mathrm{Cü}$ & 14 \\
& $\mathrm{Aa}$ & 22 \\
& $\mathrm{Ba}$ & 27 \\
\hline
\end{tabular}

\section{Alt Örneklemlerin Belirlenmesi}

Araştırmanın nicel boyutunda yer alan 55 okul öncesi öğretmeni ve 57 okul öncesi öğretmen adayı içerisinden Aile Katılımı Öz-Yeterliği Değerlendirme Ölçeğinden almış oldukları puanlara göre alt örneklemleri belirlemek amacı ile amaçlı örnekleme yöntemlerinden aykırı durum örneklemesi kullanılmıştır. Araştırma kapsamında alt ve üst grupları belirlemek için şu yollar izlenmiştir;

1. Araştırmanın nicel boyutunda yer alan iki gruba da "Aile Katılımı Öz-Yeterliği Değerlendirme Ölçeği” uygulanmıştır.

2. Okul öncesi öğretmeni ve okul öncesi öğretmen adaylarının ölçekten aldıkları puanların ortalaması ve standart sapmaları aşağıda yer alan formül ile belirlenmiştir.

$$
\begin{array}{lccc}
\text { Aritmetik Ortalama } & + & \text { üst grup } \\
\text { Aritmetik Ortalama } & - & \frac{\text { standart sapma }}{2}< & \text { alt grup }
\end{array}
$$

3. Elde edilen puanlar kapsaminda üst ve alt gruplar her iki gruptan da toplam katılimc1 sayısının \%10 u olacak şekilde belirlenmiştir. Okul öncesi öğretmenlerinden üç üst grup ve üç alt grup olacak şekilde altı öğretmen ve okul öncesi öğretmen adaylarından üç üst grup ve üç 
alt grup olacak şekilde altı öğretmen adayı ile yarı-yapılandırılmış görüşmeler gerçekleştirilmiştir.

\section{Veri Toplama Araci}

Bu araştırmada yanıt aranan alt problemlere cevap bulabilmek adına iki farklı veri toplama aracına yer verilmiştir. Nicel verilerin elde edilmesinde Aile Katılımı Öz-Yeterliği Değerlendirme Ölçeği kullanılmıştır. Nitel verilerin elde edilmesinde ise araştırmacı tarafından geliştirilen yarıyapılandırılmış görüşme soruları kullanılmıştır. Veri toplama araçları aşağıda detaylı bir şekilde tanitılmıştır.

\section{Aile Katılımı Öz-Yeterliği Değerlendirme Ölçeği}

Aile Katılımı Öz-Yeterliği Değerlendirme Ölçeği ilk olarak Stuckey (2010) tarafindan geliştirilmiş 11 maddeli altılı likert tipli bir ölçektir. Orijinal adı "Assessment of Parent Involvement Efficacy" olan ölçeğin Stuckey (2010) tarafından Cronbach's Alpha güvenirlik katsayısı .83 olarak tespit edilmiştir. Stuckey ölçekten elde edilen puanları 60-46 arası yüksek, 45-31 arası orta ve 30 ve altı düşük öz-yeterlik inanc1 şeklinde sınıflandırmıştır. Aynı kategorizasyon, ölçeğin Türkçe versiyonunda da uygulanmıştır. Ölçeğin Türkçeye uyarlaması Alaçam (2015) tarafindan gerçekleştirilmiş ve bu süreçte uzman görüşleri alınmış, pilot çalışma yapılmış ve ölçeğin geçerlik ve güvenilirliği çeşitli istatiksel analizlerle teyit edilmiştir ve ölçeğin tek faktörlü bir yapıya sahip olduğu sonucuna varılmıştır. 11 maddeli Aile Katılımı Öz-Yeterliği Değerlendirme Ölçeğinin Cronbach’s Alpha güvenirlik katsayısı .93 olarak elde edilmiştir.

\section{Yar1-Yapılandirılmış Görüşme Soruları}

Bu araştırmada nicel boyutta yer alan katılımcı grubu arasından aykırı durum örneklemesi yöntemi ile seçilen altı okul öncesi öğretmenine ve altı okul öncesi öğretmen adayına yarı-yapılandırılmış görüşme soruları yöneltilmiştir (Tablo 2).

Tablo 2. Görüşme sorularının karakteristiği

\begin{tabular}{|c|c|c|c|}
\hline \multicolumn{3}{|c|}{ Sorular } & \multirow{2}{*}{ Veri Kaynağ1 } \\
\hline & Öğretmen & Öğretmen Adayı & \\
\hline 1 & $\begin{array}{l}\text { Aile katılımı sizce önemli mi/ gerekli } \\
\text { mi? } \\
\text { Neden? Bu konuda neler } \\
\text { söyleyebilirsiniz? (Evet, ise) Hangi } \\
\text { konularda faydalı görüyorsunuz? }\end{array}$ & $\begin{array}{l}\text { Aile katılımı sizce önemli mi/ } \\
\text { gerekli mi? } \\
\text { Neden? Bu konuda neler } \\
\text { söyleyebilirsiniz? (Evet, ise) } \\
\text { Hangi konularda faydalı } \\
\text { görüyorsunuz? }\end{array}$ & Önem/Rasyonel \\
\hline
\end{tabular}




\begin{tabular}{|c|c|c|c|}
\hline 2 & $\begin{array}{l}\text { Aile katılım çalışmaları yapıyor } \\
\text { musunuz? } \\
\text { Hayır, ise Nedenini anlatır mısınız? } \\
\mathrm{Ne} \mathrm{tür} \mathrm{zorluklarla/} \mathrm{engellerle} \\
\text { karşılaşıyorsunuz? } \\
\text { Evet, ise Neler yapıyorsunuz? (broşür, } \\
\text { kitapçk, eğitim/duyuru panosu, bireysel } \\
\text { görüsmeler, ev ziyaretleri...) Ne sıklikta } \\
\text { yapiyorsunuz? }\end{array}$ & $\begin{array}{l}\text { Uygulamaya gittiğiniz okullarda } \\
\text { günlük eğitim akışı planlama } \\
\text { aşamasında aile katılımı sürecine yer } \\
\text { veriyor musunuz? } \\
\text { Evet, ise Ne tür aile katılım } \\
\text { etkinlikleri planlıyorsunuz? }\end{array}$ & Etkinlik İçeriği/Sıklığ1 \\
\hline 3 & $\begin{array}{l}\text { Aile katılımını etkili bir şekilde } \\
\text { gerçekleştirebildiğinizi düşünüyor } \\
\text { musunuz? Neden? }\end{array}$ & $\begin{array}{l}\text { Aile katılımına yönelik hizmet içi bir } \\
\text { ders aldınız mı? } \\
\text { Öğretmen olduğunuzda, aile } \\
\text { katılımını etkili bir şekilde } \\
\text { gerçekleştirebileceğinizi } \\
\text { düşünüyor musunuz? Neden? }\end{array}$ & Öğretmen Yeterliği \\
\hline 4 & $\begin{array}{l}\text { Aile katılımı sürecinde sizi sınırlamayan } \\
\text { ve keyif aldığınız konular nelerdir? } \\
\text { Aile katılımı sürecinde sizi } \\
\text { zorlayan/sınırlayan konular var ise } \\
\text { bunlar nelerdir? } \\
\text { Aile katılımında yaşamış olduğunuz } \\
\text { olumlu ve olumsuz durumları anlatır } \\
\text { mısınız? } \\
\text { Yaşamış olduğunuz olumsuz } \\
\text { durumlarda engellerin üstesinden } \\
\text { gelmek için nasıl bir yol izlemiştiniz? }\end{array}$ & $\begin{array}{l}\text { Aile katılım etkinliklerine yer } \\
\text { verirken sizi sınırlamayan ve keyif } \\
\text { aldığınız konular nelerdir? } \\
\text { Eğer zorlayan/sınırlayan } \\
\text { konular var ise bunlar nelerdir? } \\
\text { Aile katılımına yönelik olası } \\
\text { engellerin üstesinden gelmek } \\
\text { için nasıl bir yol izlersiniz? }\end{array}$ & $\begin{array}{l}\text { Olumlu ve Olumsuz } \\
\text { Durumlar }\end{array}$ \\
\hline 5 & $\begin{array}{l}\text { Aile katılımını arttırmak adına nasıl bir } \\
\text { uygulama/strateji geliştirirsiniz? }\end{array}$ & $\begin{array}{l}\text { Aile katılımını arttırmak adına nasıl } \\
\text { bir uygulama/strateji geliştirirsiniz? }\end{array}$ & $\begin{array}{l}\text { Niteliği arttırma } \\
\text { stratejileri }\end{array}$ \\
\hline
\end{tabular}

Araştırmacı tarafından geliştirilen yarı-yapılandırılmış görüşme soruları belirlenmeden önce gerekli literatür taraması yapılmış ve benzer çalışmalar incelenmiştir. İncelenen çalışmalar neticesinde araştırmacı amaca yönelik yarı-yapılandırılmış görüşme sorularını oluşturmuştur. Araştırmacı tarafından görüşme sorularını geliştirmek ve soruların iç geçerliğini ve dış denetimini sağlamak adına okul öncesi eğitimi alanında uzman olan iki öğretim üyesinden uzman görüşü alınmıştır(Yıldırım ve Şimşek, 2013). Almış olunan uzman görüşü kapsamında düzenlenen yarıyapılandırılmış görüşme sorularının net ve anlaşılır olup olmadığı ve araştırmanın amacına ne kadar hizmet edeceğini belirlemek amacı ile araştırmacı tarafından pilot bir çalışma gerçekleştirilmiş ve bir okul öncesi öğretmeni ve öğretmen adayı ile görüşmeler yapılmıştır. Araştırmacı daha sonra cevapların bulunduğu birer adet formu kontrol etmeleri için uzmanlara tekrar göndermiş, buradan gelen dönütler doğrultusunda sorulara nihai halini vermiş ve uygulamaya hazır hale getirmiştir.

\section{Verilerin Toplanması ve Analizi}

Veri toplama sürecinde Denizli Pamukkale ilçesinde görev yapmakta olan okul öncesi öğretmenlerinin çalıştıkları kurumlara ulaşılmıştır. Verileri toplamak için alınmış olan etik kurul izni kapsamında Aile Katılımı Öz-Yeterliği Değerlendirme Ölçeği öğretmenlere verilmiştir. Öğretmenlere verilen veri toplama araçları bir gün sonra öğretmenlerden toplanmıştır. Pamukkale 
Üniversitesi Eğitim Fakültesinde öğrenim gören okul öncesi öğretmen adaylarına ise ölçek uygulanmadan önce alanında uzman öğretmen ile görüşülmüş ve ölçeği uygulatabilmek için gerekli izin ve randevu alınmıştır. Daha sonra 4. Sınıfta öğrenim gören öğretmen adaylarının ders saatinde sınıfta öncelikle öğrencilere çalışmanın amacı anlatılmıştır. Amaç kapsamında öğretmen adaylarına ölçek uygulanmıştır. Araştırmanın nicel boyutunda katılım gösteren toplam 55 okul öncesi öğretmeni ve 57 okul öncesi öğretmen adaylarının ölçekten aldıkları puanlar hesaplanmıştır. Bu kapsamda üç alt boyut ve üç üst boyutta yer alan toplam alt1 öğretmen ve altı öğretmen adayına ulaşılmıştır. Öğretmen ve öğretmen adayları ile iletişime geçilmiştir. Her bir öğretmen ve öğretmen adayından yarı-yapılandırılmış görüşmeyi gerçekleştirebilmek için randevu talep edilmiş ve uygun görülen saatte görüşmeler gerçekleştirilmiştir. Nicel veriler üzerinde öncelikle normallik testi ve betimsel istatistikler gerçekleştirilmiştir. Ardından okul öncesi öğretmen ve öğretmen adaylarının aile katılımına yönelik öz-yeterlik inançlarının yaş ve kıdem değişkenlerine göre değişimi Kruskal Wallis-H testi aracıllğıyla belirlenmiştir. Okul öncesi öğretmen ve öğretmen adaylarının aile katılımına yönelik öz-yeterlik inançları arasındaki fark ve eğitim alıp almama durumlarına göre değişimin anlamlılığ ise Mann Whitney-U testi aracıllğıyla analiz edilmiştir (Büyüköztürk, 2012). Katılımcıların yarı yapılandırılmış görüşme sorularına verdikleri yanıtların analizinde tümevarımsal içerik analizi ve sürekli karşılaştırmalı yöntem kullanılmıştır. Tümevarımsal içerik analizinde öncelikle temalar ve kategoriler oluşturulur. Bu tema ve kategoriler oluşturulmasında katılımcıların ifadeleri dikkate alınır. Elde edilen ifadelerden anlamlı kümeler oluşturulur. Anlamlı kümeler katılımcıların davranışlarını ve düşüncelerini anlamada yardımcı olur. Birbirine benzeyen veriler bir araya getirilir. Verilere ilişkin sonuçlarda birlikte analiz edilir (Neuman, 2012). Sürekli karşılaştırma analizi yöntemi ise iki temel aşamadan oluşmaktadır. İlk aşamada veriler okunur ve birbirleri ile karşılaştırlır. Bu karşılaştırmalar neticesinde birbiri ile ilgili bulunan veriler belirli kavram ya da kategoriler altında toplanmaktadır. Yöntemin ikinci aşamasında öncelikli olarak kavram ve kategorilere dayalı ana temalar ortaya çıkarılır ve daha sonra bu temalar, önerme cümleleri haline getirilerek denence cümleleri kurulur (Yıldırım ve Şimşek, 2013).

\section{Geçerlik ve Güvenirlik}

Araştırmanın güven duyulabilirliğini inandırıcılık, aktarılabilirlik, güvenilebilirlik ve onaylanabilirlik ölçütleri sağlamaktadır. Bulguların, gerçeklikle ne kadar uyumlu olduğunu belirleyebilmek için inandırıcılık ölçütünden yararlanılırken, elde edilen bulguların diğer durumlara ne düzeyde uyarlanabildiği de aktarılabilirlik ölçütü ile sağlanır. Araştırma kapsamında aktarılabilirlik ölçütünü sağlamak amacı ile araştırmayı etkileyen faktörler ve örneklemi seçerken izlenen yöntemler detaylı bir şekilde açıklanmıştır. Araştırmanın güvenilebilirlik boyutu aynı katılımcı grubu ile aynı bağlamda 
ve aynı sonuçlara ulaşılmasını ifade ederken, onaylanabilirlik ise elde edilen bulguların katılımcıların düşünce ve deneyimlerinden kaynaklandığını ifade etmektedir (Shenton, 2004). Nitel araştırma kısmında verilerin inandırıcılığını sağlamak için alanında uzman olan iki uzman görüşünden yararlanılmıştır. Araştırma konusu ile ilgili genel bir bilgiye sahip uzman kişilerden yardım istenmiştir. Burada uzman kişiden görüş alınmasındaki amaç araştırmacının yaklaşımının geçerliğini değerlendirmekle birlikte geri bildirimde bulunmak ve araştırma deseni, veri toplama, analiz, sonuçlara ulaşma ve yorum aşamalarının geçerli ve tutarlı olmasını sağlamaktır (Yıldırım ve Şimşek, 2013).

\section{BULGULAR}

Bu bölümde okul öncesi öğretmen ve öğretmen adaylarının yanıtlamış olduğu Aile Katılımı ÖzYeterliğini Değerlendirme Ölçeği ile yarı-yapılandırılmış görüşme sorularının analizinden elde edilen bulgular sunulmuştur. İlk olarak katılımcıların Aile Katılımı Öz-Yeterliği Değerlendirme Ölçeğine vermiş oldukları yanıtlar doğrultusunda ölçek puanlarına ilişkin normallik testi sonuçları verilerek toplam ve madde bazlı betimsel istatistik değerleri sunulmuştur. Ardından Kruskal Wallis H Testi ve Mann Whitney U Testleri sonuçları ile yarı-yapılandırılmış görüşme sorularına verdikleri yanıtlar üzerinden gerçekleştirilen tümevarımsal içerik analizi ve sürekli karşılaştırmalı yöntem sonuçlarına yer verilmiştir.

Tablo 3. Okul öncesi öğretmen ve öğretmen adaylarının Kolmogorov-Smirnov normallik testi sonuçları

\begin{tabular}{lccccc}
\hline & $\mathbf{N}$ & $\mathbf{X}$ & $\mathbf{S . S}$ & $\mathbf{Z}$ & $\mathbf{p}$ \\
\hline Öğretmen & 55 & 53,6727 & 11,50049 &, 206 &, 000 \\
Ö̆ğretmen Aday1 & 57 & 51,0526 & 8,98694 &, 208 &, 000 \\
\hline
\end{tabular}

Tablo 3 incelendiğinde çalışma grubunda yer alan okul öncesi öğretmenlerinden ve öğretmen adaylarından toplanan verilerin (toplam puan) normal dağılım göstermediği $(\mathrm{p}<, 05)$ tespit edilmiştir. Toplam puanların normal dağılım göstermemesi, veriler üzerinde non parametrik testlerin uygulanabileceği anlamına gelir. Bu sebeple okul öncesi öğretmenlerinin ve öğretmen adaylarının aile katılımına yönelik öz-yeterlik inançları ile mesleki kıdemleri, yaşları ve aile katılımına yönelik eğitim alıp almama durumları arasındaki farkın anlamlılı̆̆1, Kruskal Wallis H-Testi ve Mann Whitney U-Testi ile belirlenmiştir. 
Tablo 4. Okul öncesi öğretmenlerinin aile katılımına yönelik öz-yeterlik inançlarının seviyesine dair madde bazlı betimsel analiz bulguları

\begin{tabular}{cccccc}
\hline $\begin{array}{c}\text { Aile Kat1lımına } \\
\text { Yönelik Öz- } \\
\text { Yeterlik }\end{array}$ & N & Minimum & Maximum & Ortalama & $\begin{array}{c}\text { Standart } \\
\text { Sapma }\end{array}$ \\
\hline Soru 1 & 55 & 1 & 6 & 4,82 & 1,107 \\
Soru 2 & 55 & 1 & 6 & 4,91 & 1,191 \\
Soru 3 & 55 & 1 & 6 & 5,00 & 1,232 \\
Soru 4 & 55 & 1 & 6 & 4,82 & 1,188 \\
Soru 5 & 55 & 1 & 6 & 5,16 & 1,085 \\
Soru 6 & 55 & 1 & 6 & 4,93 & 1,215 \\
Soru 7 & 55 & 1 & 6 & 4,95 & 1,253 \\
Soru 8 & 55 & 1 & 6 & 4,84 & 1,085 \\
Soru 9 & 55 & 1 & 6 & 4,71 & 1,301 \\
Soru 10 & 55 & 1 & & 4,84 & 1,273 \\
Soru 11 & 55 & 2 & & 4,71 & 1,066 \\
Toplam & $\mathbf{5 5}$ & & $\mathbf{6 3 , 6 7}$ & $\mathbf{1 1 , 5 0 0 4 9}$ \\
\hline
\end{tabular}

Tablo 4 incelendiğinde okul öncesi öğretmenlerinin Aile Katılımı Öz-Yeterliği Değerlendirme Ölçeğine verdikleri cevapların ortalamaları ve standart sapmaları hesaplanmıştır. Ölçek altılı likert tipli bir ölçektir ve seçenekler "kesinlikle katılmyyorum" "katılmyyorum" "biraz, katılmuyorum" "biraz. katılyorum" "katılyyorum" "kesinlikle katıllyorum" şeklindedir. Yapılan analizler sonucunda ölçekte en yüksek ortalamaya sahip olan $(\mathrm{X}=5,16)$ "Ailelere katılımın gerekliliğini açı bir șekilde anlatabiliyorum." sorusu ile beşinci sorudur. Ölçekte yüksek ortalamaya sahip diğer bir soru ise $(X=5,00)$ " Ailelerin evde okulla ilgili etkinliklere katılımm teşvik ediyorum" ifadesi ile üçüncü sorudur. Öğretmenlerin en düşük ortalamaya sahip oldukları sorular $(\mathrm{X}=4,71)$ ise "Ailelerin okulda gönüllü olmalarm sağlama konusunda başarll olabiliyorum" ve "Ailelerin seminer gibi eğitici etkinliklere katıllmlarm sağlayabiliyorum" ifadeleri ile dokuzuncu ve on birinci sorulardır.

Tablo 5. Okul öncesi öğretmen adaylarının aile katılımına yönelik öz-yeterlik inançlarının seviyesine dair madde bazlı betimsel analiz bulguları

\begin{tabular}{|c|c|c|c|c|c|}
\hline $\begin{array}{l}\text { Aile Katılımına } \\
\text { Yönelik Öz- } \\
\text { Yeterlik }\end{array}$ & $\mathbf{N}$ & Minimum & Maksimum & Ortalama & $\begin{array}{l}\text { Standart } \\
\text { Sapma }\end{array}$ \\
\hline Soru 1 & 57 & 2 & 6 & 4,49 & ,984 \\
\hline Soru 2 & 57 & 2 & 6 & 4,58 & ,981 \\
\hline Soru 3 & 57 & 2 & 6 & 4,74 & 917 \\
\hline Soru 4 & 57 & 2 & 6 & 4,60 & 979 \\
\hline Soru 5 & 57 & 2 & 6 & 4,93 & ,923 \\
\hline Soru 6 & 57 & 2 & 6 & 4,65 & ,935 \\
\hline Soru 7 & 57 & 2 & 6 & 4,68 & 1,020 \\
\hline Soru 8 & 57 & 2 & 6 & 4,74 & ,955 \\
\hline Soru 9 & 57 & 2 & 6 & 4,47 & 1,002 \\
\hline & Erker & $\begin{array}{l}\text { k Çalış̧aları Dergisi } \\
\text { Cilt } 4 \cdot \text { Sayı } 3 \cdot \text { Ekim }\end{array}$ & $\begin{array}{l}\text { Journal of E } \\
\text { Volume } 4 \cdot \mathrm{I}\end{array}$ & $\begin{array}{l}\text { hood Studies } \\
\text { ctober }\end{array}$ & \\
\hline
\end{tabular}




$\begin{array}{llllcc}\text { Soru } 10 & 57 & 2 & 6 & 4,70 & 1,052 \\ \text { Soru } 11 & 57 & 1 & 6 & 4,47 & 1,087 \\ \text { Toplam } & 57 & & & 51,05 & 8,98694\end{array}$

Tablo 5 incelendiğinde okul öncesi öğretmen adaylarının Aile Katılımı Öz-Yeterliği Değerlendirme Ölçeğine verdikleri cevapların ortalamaları ve standart sapmaları hesaplanmıştır. Yapılan analizler sonucunda ölçekte en yüksek ortalamaya sahip olan $(\mathrm{X}=4,93)$ "Ailelere katılımın gerekliliğini aı̧ık bir şekilde anlatabileceğim." sorusu ile beşinci sorudur. Öğretmen adaylarnnın en düşük ortalamaya sahip oldukları sorular $(\mathrm{X}=4,47)$ ise "Ailelerin okulda gönüllü olmalarmı sağlama konusunda bașarlı olacağım" ve "Ailelerin seminer gibi eğitici etkinliklere katıllmlarm sağlayabileceğim" ifadeleri ile dokuzuncu ve on birinci sorulardır. Elde edilen bulgular neticesinde okul öncesi öğretmen ve öğretmen adaylarının yüksek ve düşük ortalamaya sahip sorularda aynı paydada buluştukları görülmektedir.

\section{Okul Öncesi Öğretmenlerinin Aile Katılımına Yönelik Öz-yeterlik İnançlarının Değişimine İlişkin Bulgular}

Okul öncesi öğretmenlerinin kıdem, yaş ve aile katılımı ile ilgili eğitim alıp almama durumlarının aile katılımına yönelik öz-yeterlik inançlarında herhangi bir farklılaşmaya yol açıp açmadığını belirleyebilmek amacı ile nicel analizler gerçekleştirilmiştir. Bu araştırma problemini yanıtlamak için yapılan nicel analizlerden elde edilen bulgular, belirli tabloların yardımı ile detaylı bir şekilde aktarılmıştır.

Tablo 6. Okul öncesi öğretmenlerinin aile katılımına yönelik öz-yeterlik inançlarının kıdem değişkenine göre Kruskal Wallis-H Testi sonuçları

\begin{tabular}{cccccccc}
\hline $\begin{array}{c}\text { Meslekî } \\
\text { Kidem }\end{array}$ & N & Ortalama & $\begin{array}{c}\text { Standart } \\
\text { Sapma }\end{array}$ & $\begin{array}{c}\text { Sira } \\
\text { Ortalaması }\end{array}$ & $\begin{array}{c}\text { Serbestlik } \\
\text { Derecesi } \\
\text { (SD) }\end{array}$ & $\mathbf{X}^{2}$ & $\mathbf{P}$ \\
\hline 1-5 Y1l & 13 & 45,76 & 16,28 & 19,35 & 3 & 5,466 &, 141 \\
6-10 Yil & 13 & 55,38 & 9,84 & 29,88 & & & \\
11-15 Y1l & 11 & 55,00 & 8,79 & 28,55 & & & \\
15 Y1l ve Üzeri & 18 & 57,33 & 7,64 & 32,56 & & & \\
Toplam & 55 & 53,67 & 11,50 & & & & \\
\hline
\end{tabular}

Tablo 6 incelendiğinde okul öncesi öğretmenlerinin aile katılımına yönelik öz-yeterlik değerlendirme ölçeğinden elde ettikleri mesleki kıdem bağımsız değişkeni toplam puanları ile aile katılımına yönelik öz-yeterlik inançları arasında anlamlı bir farklılaşma tespit edilmemiştir $(p=, 141)$. Öğretmenlerin mesleki kıdemleri dikkate alındığında aile katılımına yönelik öz-yeterlik inançlarında en düşük ortalamaya sahip olan kıdem yılının 1-5 yıl arası olduğu saptanmıştır (X=45,76). En yüksek ortalamanın ise 15 yıl ve üzeri kıdem yılına sahip olan öğretmenlere ait olduğu tespit edilmiştir $(\mathrm{X}=57,33)$. 
Tablo 7. Okul öncesi öğretmenlerinin aile katılımına yönelik öz-yeterlik inançlarının yaş değişkenine göre Kruskal Wallis-H Testi sonuçları

\begin{tabular}{|c|c|c|c|c|c|c|c|}
\hline Yaş Grubu & $\mathbf{N}$ & Ortalama & $\begin{array}{l}\text { Standart } \\
\text { Sapma }\end{array}$ & $\begin{array}{c}\text { Sira } \\
\text { Ortalamas1 }\end{array}$ & $\begin{array}{c}\text { Serbestlik } \\
\text { Derecesi } \\
\text { (SD) }\end{array}$ & $\mathbf{X}^{2}$ & $\mathbf{P}$ \\
\hline 21-26 Yaş & 10 & 46,50 & 17,92 & 21,75 & 4 & 4,669 & ,323 \\
\hline 27-32 Yaş & 10 & 50,20 & 12,09 & 22,60 & & & \\
\hline 33-38 Yaş & 14 & 56,00 & 8,46 & 30,43 & & & \\
\hline 39-44 Yaş & 9 & 58,88 & 4,62 & 34,50 & & & \\
\hline 45 Yaş ve Üzeri & 12 & 55,91 & 8,60 & 30,00 & & & \\
\hline Toplam & 55 & 53,67 & 11,50 & & & & \\
\hline
\end{tabular}

Tablo 7 incelendiğinde okul öncesi öğretmenlerinin yaş bağımsız değişkeni ile aile katılımına yönelik öz-yeterlik inançları arasında anlamlı bir farklılaşma olmadığı saptanmıştır (p=,323). Öğretmenlerin yaş bağımsız değişkeni dikkate alındığında 21-26 yaş öğretmenlerin aile katılımına yönelik özyeterlik inançları kapsamında en düşük ortalamaya sahip oldukları $(X=46,20)$ en yüksek ortalamaya sahip öğretmenlerin ise 39-44 yaş arasında oldukları tespit edilmiştir $(X=58,88)$.

Tablo 8. Okul öncesi öğretmenlerinin aile katılımına yönelik öz-yeterlik inançlarının eğitim alıp almama durumuna göre Mann Whitney-U Testi sonuçları

\begin{tabular}{lccccccc}
\hline Grup & N & Ortalama & $\begin{array}{c}\text { Standart } \\
\text { Sapma }\end{array}$ & $\begin{array}{c}\text { Sira Ortalamas1 } \\
\text { (SO) }\end{array}$ & $\begin{array}{c}\text { Sira } \\
\text { Toplami }\end{array}$ & U & P \\
\hline Hayır & 22 & 53,09 & 9,97 & 25,91 & 570,00 & 317,00 &, 428 \\
Evet & 33 & 54,06 & 12,54 & 29,39 & 970,00 & & \\
\hline
\end{tabular}

Tablo 8 incelendiğinde okul öncesi öğretmenlerinin aile katılımına yönelik eğitim alıp almama durumunu hayır ve evet olarak yanıtlayan iki grubun puanları arasında anlamlı bir farklılaşma tespit edilmemiştir $(p=, 428)$. Öğretmenlerin aile katılımına yönelik eğitim alıp almama durumlarına verdikleri evet cevaplarının daha yüksek bir ortalamaya sahip olduğu saptanmıştır $(X=54,06)$.

\section{Okul Öncesi Öğretmen Adaylarının Aile Katılımına Yönelik Öz-Yeterlik İnançlarının Değişimine İlişkin Bulgular}

Okul öncesi öğretmen adaylarının yaş ve aile katılımı ile ilgili eğitim alıp almama durumlarının aile katılımına yönelik öz-yeterlik inançlarında herhangi bir farklılaşmaya yol açıp açmadığını belirleyebilmek amacı ile nicel analizler gerçekleştirilmiştir. Bu araştırma problemini yanıtlamak için yapılan nicel analizlerden elde edilen bulgular, belirli tabloların yardımı ile detaylı bir şekilde aktarılmıştır. 
Tablo 9. Okul öncesi öğretmen adaylarının aile katılımına yönelik öz-yeterlik inançlarının yaş değişkenine göre Kruskal Wallis-H Testi sonuçları

\begin{tabular}{cccccccc}
\hline Yaş Grubu & N & Ortalama & $\begin{array}{c}\text { Standart } \\
\text { Sapma }\end{array}$ & $\begin{array}{c}\text { Sira } \\
\text { Ortalamasi }\end{array}$ & $\begin{array}{c}\text { Serbestlik } \\
\text { Derecesi (SD) }\end{array}$ & $\mathbf{X}^{2}$ & $\mathbf{p}$ \\
\hline 18-21 Yaş & 25 & 51,80 & 10,14 & 29,42 & 2 &, 365 &, 833 \\
22-25 Yaş & 30 & 50,26 & 8,32 & 28,23 & & & \\
26 Yaş ve Üzeri & 2 & 53,50 &, 70 & 35,25 & & \\
Toplam & 57 & 51,05 & 8,98 & & & \\
\hline
\end{tabular}

Tablo 9 incelendiğinde okul öncesi öğretmen adaylarının yaş bağımsız değişkeni ile aile katılımına yönelik öz-yeterlik inançları arasında anlamlı bir farklılaşma olmadığı saptanmıştır ( $p=, 833)$. Öğretmen adaylarının yaş bağımsız değişkenleri dikkate alındığında aile katılımına yönelik özyeterlik inancinda en düşük ortalamaya sahip yaş grubunun 22-25 yaş grubu olduğu tespit edilmiştir $(X=50,26)$.

Tablo 10. Okul öncesi ögretmen adaylarının aile katılımına yönelik öz-yeterlik inançlarının eğitim alıp almama durumuna göre Mann Whitney-U Testi sonuçları

\begin{tabular}{lccccccc}
\hline Grup & $\mathbf{N}$ & Ortalama & $\begin{array}{c}\text { Standart } \\
\text { Sapma }\end{array}$ & $\begin{array}{c}\text { Sira Ortalamas1 } \\
\text { (SO) }\end{array}$ & $\begin{array}{c}\text { Sira } \\
\text { Toplami }\end{array}$ & $\mathbf{U}$ & $\mathbf{p}$ \\
\hline Hayır & 17 & 50,11 & 11,85 & 29,47 & 501,00 & 332,00 &, 889 \\
Evet & 40 & 51,45 & 7,59 & 28,80 & 1152,00 & & \\
\hline
\end{tabular}

Tablo 10 incelendiğinde okul öncesi öğretmen adaylarının aile katılımına yönelik eğitim alıp almama durumunu hayır ve evet olarak yanıtlayan iki grubun puanları arasında anlamlı bir farklılaşma tespit edilmemiştir $(p=, 889)$. Öğretmen adaylarının aile katılımına yönelik eğitim alıp almama durumuna verdikleri yanıtta evet cevabının daha yüksek bir ortalamaya sahip olduğu saptanmıştır $(X=51,45)$.

\section{Okul Öncesi Öğretmen ve Öğretmen Adaylarının Aile Katılımına Yönelik Öz-Yeterlik İnançlarındaki Farklılaşmaya İlişkin Bulgular}

Okul öncesi öğretmenlerinin ve öğretmen adaylarının Aile Katılımı Öz-Yeterliği Değerlendirme Ölçeğinden elde ettikleri toplam puanlar dikkate alınarak iki grup arasındaki aile katılımına yönelik Öz-yeterlik inançları arasındaki farklılaşma tespit edilmeye çalışılmıştır. Bu araştırma problemini yanıtlamak için yapılan nicel analizden elde edilen bulgular, belirli tablonun yardımı ile detaylı bir şekilde aktarılmıştır. 
Tablo 11. Okul öncesi öğretmen ve öğretmen adaylarının aile katılımına yönelik öz-yeterlik inançları arasındaki Mann Whitney U Testi sonuçları

\begin{tabular}{lccccccc}
\hline Grup & N & Ortalama & $\begin{array}{c}\text { Standart } \\
\text { Sapma }\end{array}$ & $\begin{array}{c}\text { Sira } \\
\text { Ortalamas1 }\end{array}$ & $\begin{array}{c}\text { Sira } \\
\text { Toplami }\end{array}$ & U & P \\
\hline Öğretmen & 55 & 54,54 & 11,43 & 66,92 & 3680,50 & 994,500 &, 001 \\
Öğretmen & 57 & 50,40 & 10,08 & 46,45 & 2647,50 & & \\
Aday1 & & & & & & \\
\hline
\end{tabular}

Tablo 11 incelendiğinde okul öncesi öğretmen ve okul öncesi öğretmen adaylarının AKÖYD Ölçeği toplam puanları arasında anlamlı bir farklılaşma saptanmıştır $(\mathrm{p}=, 001)$. Tespit edilen bu farklılaşma öğretmenlerin lehinedir. Elde edilen bulgularda öğretmenlerin ortalamasının $(X=54,54)$ öğretmen adaylarının ortalamalarından yüksek olduğu tespit edilmiştir $(X=50,40)$.

\section{Okul Öncesi Öğretmen ve Öğretmen Adaylarının Aile Katılımına Yönelik Öz-Yeterlik İnançlarında Etkili Olan Faktörler}

Okul öncesi öğretmen ve öğretmen adaylarının aile katılımına yönelik öz-yeterlik inançlarını inceleme amaçlı yapılan bu araştırmada nicel bulgular, katılımcıların öz-yeterliklerinin genel anlamda yüksek ve birbirlerine yakın değerde olduğunu göstermiştir. Fakat okul öncesi öğretmen adaylarıyla kıyaslandığında öğretmenlerin aile katılımı etkinliklerini gerçekleştirme bağlamında kendilerine daha fazla güvendikleri tespit edilmiştir. Bu farkın altında yatan nedenleri ve okul öncesi öğretmen ve öğretmen adaylarının değindikleri faktörleri daha derinlemesine tespit etmek için her bir gruptan en yüksek ve en düşük puan alan üçer katılımcı (toplamda 12) ile yarı yapılandırılmış görüşmeler gerçekleştirilmiştir. Katılımcıların yarı yapılandırılmış görüşme sorularına verdikleri yanıtların analizinden elde edilen bulgular beş ana başlık altında sunulmuştur. Ayrıca tümevarımsal içerik analizi sonrası ortaya çıkan öğretmen kavramsallaştırmaları Tablo 12, öğretmen adayı kavramsallaştırmaları ise Tablo 13'de yer almaktadır.

Tablo 12. Aile katılımına yönelik öğretmen kavramsallaştırmaları

\begin{tabular}{|c|c|c|c|c|}
\hline \multirow{2}{*}{ Soru Karakteristiği } & \multicolumn{2}{|c|}{ Öğretmen Üst } & \multicolumn{2}{|c|}{ Öğretmen Alt } \\
\hline & Tema & Kavram & Tema & Kavram \\
\hline \multirow[b]{2}{*}{ Önem/Rasyonel } & Sosyal Etkileşim & $\begin{array}{l}\text { Kuralların } \\
\text { uygulanması } \\
\text { Okul-Aile İletişimi } \\
\text { Sorun çözme }\end{array}$ & Sosyal Etkileşim & $\begin{array}{l}\text { Duygusal bağ } \\
\text { Öğretmeni anlama }\end{array}$ \\
\hline & Öğrenme Süreci & $\begin{array}{l}\text { Hazır bulunuşluk } \\
\text { Anlamlı-kalıcı } \\
\text { öğrenme } \\
\text { İnformal katılım } \\
\text { Bilişsel ve dil } \\
\text { gelişimi }\end{array}$ & $\begin{array}{l}\text { Eğitim-Öğretimin } \\
\text { Kalitesi }\end{array}$ & $\begin{array}{l}\text { Müfredattaki gelişim } \\
\text { alanları } \\
\text { Nitelikli öğrenme }\end{array}$ \\
\hline
\end{tabular}




\begin{tabular}{|c|c|c|c|c|}
\hline \multirow{4}{*}{ Etkinlik İçeriği/Sılklığ1 } & Siklık & $\begin{array}{l}\text { Dönemde iki kez } \\
\text { (2) } \\
\text { Haftada iki kez }\end{array}$ & \multirow[t]{2}{*}{ Siklik } & \multirow[t]{2}{*}{ Haftada bir kez (3) } \\
\hline & Sosyal Etkileşim & $\begin{array}{l}\text { Okula uyum } \\
\text { Sosyal etkileşim }\end{array}$ & & \\
\hline & Geri Bildirim & $\begin{array}{l}\text { Veli toplantıs1 } \\
\text { Bireysel görüşme } \\
\text { Geri bildirim } \\
\text { Planlama }\end{array}$ & \multirow[t]{2}{*}{ Öğrenme Süreci } & \multirow{2}{*}{$\begin{array}{l}\text { Pano hazırlama } \\
\text { Oyun } \\
\text { Çocuk edebiyatı } \\
\text { Drama }\end{array}$} \\
\hline & Öğrenme Süreci & $\begin{array}{l}\text { Fen öğretimi } \\
\text { Çocuk edebiyatı } \\
\text { İnformal öğrenme }\end{array}$ & & \\
\hline \multirow{3}{*}{ Öğretmen Yeterliği } & Olumlu Görüşler & Yeterli (3) & $\begin{array}{l}\text { Olumsuz } \\
\text { Görüşler }\end{array}$ & Yetersiz (3) \\
\hline & \multirow{2}{*}{ Sosyal İletişim } & \multirow{2}{*}{$\begin{array}{l}\text { Empati } \\
\text { Duygusal bağlılık }\end{array}$} & Sosyal İletişim & $\begin{array}{l}\text { Aile ile iletişim } \\
\text { Aile kaynaklı } \\
\text { bariyerler }\end{array}$ \\
\hline & & & Deneyim & $\begin{array}{l}\text { Hizmet öncesi } \\
\text { eğitim } \\
\text { Meslekî deneyim }\end{array}$ \\
\hline \multirow{2}{*}{$\begin{array}{c}\text { Olumlu ve Olumsuz } \\
\text { Durumlar }\end{array}$} & $\begin{array}{l}\text { Aile kaynakl1 } \\
\text { bariyerler }(-)\end{array}$ & $\begin{array}{l}\text { Ailenin ilgisizliği } \\
\text { Eleștiriye tahammül } \\
\text { İletişimsel engeller }\end{array}$ & $\begin{array}{l}\text { Aile kaynakl1 } \\
\text { bariyerler }(-)\end{array}$ & $\begin{array}{l}\text { Ailenin ilgisizliği } \\
\text { Eleștiriye tahammül } \\
\text { İletşimsel engeller }\end{array}$ \\
\hline & $\begin{array}{l}\text { Sosyal etkileşim } \\
(+)\end{array}$ & $\begin{array}{l}\text { Duygusal bağlllık } \\
\text { Babaların katılımı } \\
\text { Empati }\end{array}$ & $\begin{array}{l}\text { Öğretmen } \\
\text { Yeterliği (-) }\end{array}$ & $\begin{array}{l}\text { Pedagojik yetersizlik } \\
\text { Özgüven eksikliği } \\
\text { Etkinlik hazırlama }\end{array}$ \\
\hline \multirow{2}{*}{$\begin{array}{l}\text { Niteliği arttırma } \\
\text { stratejileri }\end{array}$} & $\begin{array}{l}\text { Sosyal etkileşimi } \\
\text { arttırma }\end{array}$ & $\begin{array}{l}\text { Okul dişı sosyal } \\
\text { etkinlikler } \\
\text { Ev ziyaretleri }\end{array}$ & Yetişkin eğitimi & $\begin{array}{l}\text { Bilgilendirme } \\
\text { Yetişkin eğitimi }\end{array}$ \\
\hline & $\begin{array}{l}\text { Katılımı } \\
\text { genişletme }\end{array}$ & Planlamaya katılım & Öğretmen eğitimi & $\begin{array}{l}\text { Hizmet öncesi } \\
\text { eğitim } \\
\text { Hizmet içi eğitim }\end{array}$ \\
\hline
\end{tabular}

\section{Aile Katılımonın Önemi}

$\mathrm{Bu}$ araştırmaya katılan okul öncesi öğretmenlerine aile katılımının önemine dair kavramsallaştırmalarını tespit etmek amacıyla "Aile katılımı siz̧ce önemli mil gerekli mi? Neden? Bu konuda neler söyleyebilirsiniz? (Evet, ise) Hangi konularda faydal görüyorsunuz?" şeklindeki sorular yöneltilmiştir. Buna göre öğretmenlerin öz-yeterlik puanından bağımsız olarak temel anlamda iki temaya yoğunlaştıklan görülmüştür. Hem üst hem de alt gruptaki öğretmenlerin aile katılımını önemli gördükleri ve sosyal etkileşime atıf yaptıkları tespit edilmiştir.

$\ddot{O}_{\text {2üst }}$ : Çok önemli.Velinin okul içerisindeki olaylara her zaman bir merakı vardır. Bize verilen vaatler gerçekten uygulanıyor ama gerçekten bize bu söyleniyor ama söylenenle yapılan tutuyor mu peki bur da aile katılımına gelindiğinde buna birebir yaşanılanları gördüğünde öğretmende veliler aile katılımından memnun kalıyor. Ben de bu vesileyle velilerle her zaman irtibat halindeyim velilerimde bu konudan kendilerine geri çekmiyorlar. Bu şekilde olunca veliler birbirleri ile de iletişim halindeler çocuk alırken çocuk bırakırken iletişim halindeler devamlı okul kahvaltıları olsun bu şekilde buluşmalar da birer aile katılımidir. 
$\ddot{O}_{3 a l t}$ : Gerekli olduğunu düşünüyorum. Çünkü çocukların zamanlarının çoğu okulda bizimle geçiyor. Bu sebeple çocuklar aileleri ile de vakit geçirmek istiyorlar, onları özlüyorlar. Aile katılımı sayesinde daha çok bir arada olma birlikte bir şeyler yapma imkânı buluyorlar. Böyle olması çocukları mutlu ediyor ve hoşlarına gidiyor. Bazı konularda faydalı görüyorum.

Öğretmen açıklamalarından örnek alıntılarda da görülebileceği üzere üst gruptaki öğretmenlerden biri aile katılımının iletişimi sağlamak açısından önemli olabileceğini öne sürerken alt gruptaki bir öğretmen ise duygusal bağın bozulmamasını sağlamak için aile katılımına başvurduğunu belirtmiştir. Diğer yandan aile katılımı süreçlerinin önemi hakkında öğretmen adaylarının nasıl kavramsallaştırmalar yaptıklarını belirlemek için ise "Aile katıllm siz̧ce önemli mil gerekli mi? Neden? Bu konuda neler söyleyebilirsiniz̨? (Evet, ise) Hangi konularda faydah görüyorsunuz??" şeklindeki sorular yöneltilmiştir. Bu soruları yanıtlayan öğretmen adaylarının da öz-yeterlik puanından bağımsız olarak aynı iki temaya atıf yaptıkları tespit edilerek sosyal etkileşim ve ögrrenme sürecine değindikleri saptanmıştır.

$\ddot{\boldsymbol{O}} \boldsymbol{A}_{2 \text { iust: }}$ Aile katılımını gerekli görüyorum. Zaten aile katılımında da bana göre amaç okul ile ev arasındaki koordinasyonu sağlayarak çocukların gelişimlerinde ve eğitimlerinde birlikte hareket edebilme durumunu geliştirmektir ve çocukların eğitim sürecini desteklemektir.

$\ddot{\boldsymbol{O}} \boldsymbol{A}_{\text {Ialt: }}$ Bence önemli ama çocuklar hem okulda hem evde farkl1lık yaşıyor. Çünkü çocuklar evde ayrıcalıklı bir durum gördükleri ve her istedikleri yapıldığı için okula gelince neye uğradıklarını şaşırıyorlar ve kuralları kabullenemiyorlar. Bu sebeple bence aile ile iletişimde kalabilmek etkili oluyor.

Alt ve üst gruptaki öğretmen adaylarının örnek alıntılarda da görülebileceği üzere aile katılımının koordinasyon ve okula uyum temelinde sosyal etkileşim açısından önemine vurgu yaptıkları tespit edilmiştir.

Tablo 13. Aile katılımına yönelik öğretmen adayı kavramsallaştırmaları

\begin{tabular}{|c|c|c|c|c|}
\hline \multirow{2}{*}{ Soru Karakteristiği } & \multicolumn{2}{|c|}{ Öğrretmen Adayı Üst } & \multicolumn{2}{|c|}{ Öğretmen Adayı Alt } \\
\hline & Tema & Kavram & Tema & Kavram \\
\hline \multirow{2}{*}{ Önem/Rasyonel } & Sosyal Etkileşim & $\begin{array}{l}\text { Koordinasyon } \\
\text { Okul-aile iletişimi }\end{array}$ & Sosyal Etkileşim & $\begin{array}{l}\text { Koordinasyon } \\
\text { Okula uyum } \\
\text { Kurallarin } \\
\text { uygulanmas1 }\end{array}$ \\
\hline & Öğrenme Süreci & $\begin{array}{l}\text { Müfredattaki gelişim } \\
\text { alanları } \\
\text { Anlamlı-kalıcı } \\
\text { öğrenme }\end{array}$ & Öğrenme Süreci & $\begin{array}{l}\text { Müfredattaki gelişim } \\
\text { alanları }\end{array}$ \\
\hline \multirow[t]{2}{*}{ Etkinlik İçeriği } & $\begin{array}{l}\text { Bariyer ve } \\
\text { sinırliliklar }\end{array}$ & $\begin{array}{l}\text { Planlama düzeyinde } \\
\text { kalması } \\
\text { İletissim eksikliği } \\
\text { Bilimsel içerik }\end{array}$ & $\begin{array}{l}\text { Bariyer ve } \\
\text { sinirliliklar }\end{array}$ & $\begin{array}{l}\text { Öğretmenin şans } \\
\text { tanımaması } \\
\text { Staj gününün } \\
\text { yarattığ1 sınırlılık } \\
\text { Zaman sıkıntısı }\end{array}$ \\
\hline & $\begin{array}{r}\text { n Çocukluk Çalışm } \\
\text { Cilt } 4 \cdot S\end{array}$ & $\begin{array}{l}\text { Journal } \\
\text { Volum }\end{array}$ & $\begin{array}{l}\text { arly Childhood Studies } \\
\text { ssue } 3 \cdot \text { October }\end{array}$ & \\
\hline
\end{tabular}




\begin{tabular}{|c|c|c|c|c|}
\hline & Öğrenme Süreci & $\begin{array}{l}\text { Oyun etkinlikleri } \\
\text { Fen-oyun etkinliği }\end{array}$ & Öğrenme Süreci & Hikâye okuma \\
\hline \multirow{4}{*}{ Öğretmen Yeterliği } & Olumlu Görüşler & Yeterli (3) & $\begin{array}{l}\text { Olumsuz } \\
\text { Görüşler }\end{array}$ & Yetersiz (3) \\
\hline & $\begin{array}{l}\text { Hizmet öncesi } \\
\text { eğitimin niteliği }\end{array}$ & $\begin{array}{l}\text { Teorik içeriğin baskın } \\
\text { olması (-) }\end{array}$ & $\begin{array}{l}\text { Hizmet öncesi } \\
\text { eğitimin niteliği }\end{array}$ & $\begin{array}{l}\text { Teorik içeriğin } \\
\text { baskın olması(-) } \\
\text { Pratiğin yetersizliği }\end{array}$ \\
\hline & \multirow[t]{2}{*}{ Öneriler } & \multirow{2}{*}{$\begin{array}{l}\text { Uygulamalı derslerin } \\
\text { arttırılması } \\
\text { Özgüven geliştirme } \\
\text { Yönetim-öğretmen- } \\
\text { aile iletişimi }\end{array}$} & Öneriler & $\begin{array}{l}\text { Uygulamalı derslerin } \\
\text { arttırılması } \\
\text { Özgüven geliştirme } \\
\text { Yetişkin eğitimi }\end{array}$ \\
\hline & & & Bariyerler & $\begin{array}{l}\text { Deneyim } \\
\text { Aile ile iletişim } \\
\text { Kültürel farklılık }\end{array}$ \\
\hline \multirow{2}{*}{$\begin{array}{l}\text { Olumlu ve Olumsuz } \\
\text { Durumlar }\end{array}$} & $\begin{array}{l}\text { Aile kaynaklı } \\
\text { bariyerler }(-)\end{array}$ & $\begin{array}{l}\text { İletişimin sınırlanması } \\
\text { Ailenin ilgisizliği }\end{array}$ & $\begin{array}{l}\text { Öğretmen } \\
\text { kaynaklı } \\
\text { bariyerler }(-)\end{array}$ & $\begin{array}{l}\text { Rol paylaşımı } \\
\text { Iletişime dâhil } \\
\text { etmeme }\end{array}$ \\
\hline & Öğretim süreci (- & $\begin{array}{l}\text { Bilimsel içerik } \\
\text { Oyun etkinliği }\end{array}$ & Öğretim süreci (- & $\begin{array}{l}\text { Gezi etkinlikleri } \\
\text { Fen etkinliği }\end{array}$ \\
\hline \multirow{3}{*}{$\begin{array}{l}\text { Niteliği Arttırma } \\
\text { Stratejileri }\end{array}$} & $\begin{array}{l}\text { Sosyal etkileşimi } \\
\text { arttırma }\end{array}$ & $\begin{array}{l}\text { Aileler arası etkileşim } \\
\text { Empati ve iletişim }\end{array}$ & $\begin{array}{l}\text { Sosyal etkileşimi } \\
\text { arttırma }\end{array}$ & $\begin{array}{l}\text { Okul dişı etkinlikler } \\
\text { Empati } \\
\text { Ev ziyaretleri }\end{array}$ \\
\hline & $\begin{array}{l}\text { Katılimı } \\
\text { genişletme }\end{array}$ & Planlamaya katılım & $\begin{array}{l}\text { Katılimı } \\
\text { genişletme }\end{array}$ & Planlamaya katılım \\
\hline & Yetişkin Eğitimi & $\begin{array}{l}\text { Giriş etkinlikleri } \\
\text { Ailenin } \\
\text { bilgilendirilmesi } \\
\text { Yetişkin eğitimi }\end{array}$ & Yetişkin Eğitimi & Yetişkin eğitimi \\
\hline
\end{tabular}

\section{Aile Katılim Etkinlikleri}

Öz-yeterlik puanlarına göre alt ve üst gruplardaki katılımcıların aile katılımı etkinliklerinin içeriğine yönelik kavramsallaştırmalarını belirlemek amacıyla öğretmenlere “Aile katılım çalıs̆malar yapıyor musunuz? Hayır, ise Nedenini anlatır musinı?? Ne tür zorluklarlal engellerle karşlaşıyorsunuz? Evet, ise Neler yapıyorsunuz? (broşür, kitapçı, eğitim/duyuru panosu, bireysel görüsmeler, ev ziyaretleri...) Ne sıkllkta yapıyorsunuг??’ şeklinde soru yöneltilmiştir. Tümevarımsal içerik analizi sonuçları, aile katılımına yönelik etkinlik içeriği ve yer verme sıklığının hem öğretmen ve öğretmen adayları hem de alt ve üst gruplar arasında farklılıklar olduğunu göstermiştir. Buna göre alt gruptaki öğretmenlerin üst gruptaki öğretmenlere göre aile katılımı etkinliklere daha sık yer verdikleri ortaya çıkmıştır. Bununla birlikte üst gruptaki öğretmenlerin aile katılımı etkinliklerinde daha çok geri bildirime ağırlık verdikleri görülürken alt gruptaki öğretmenlerin ise aileleri daha formal aktivitelere dâhil ettikleri tespit edilmiştir.

$\ddot{\boldsymbol{O}}_{\text {lüst}}$ Bireysel görüşme daha etkili oluyor o sebeple en çok onu tercih ediyorum. Çünkü veliler broşür tarzı şeyleri okumuyorlar. Onlar da bireysel görüşmelerde kendilerini daha rahat hissediyorlar. Dönem başı ve dönem sonu olmak üzere üçer dörder dakikalık görüşmeler gerçekleştiriyorum. Çocuğun gelişiminden, durumundan haberdar ediyorum. Onun haricinde genelde çocukları alıp bırakırken de kısa görüşmelerimiz oluyor. 
$\ddot{\boldsymbol{O}}_{3 a l t}:$ Velilerimiz okula gelerek etkinlik yaptırıyorlar. Oyunlar oynuyorlar, kitap okuyorlar. İsteyen olursa drama çalışması yaptırıyor. Bazı veliler deney yaptırmak istiyorlar. Bu nokta da biraz velinin isteğine bırakıyorum kendilerini rahat hissetmeleri açısından.

Öğretmen adaylarına ise "Uygulamaya gittiğiniz, okullarda günlük eğitim akıı̧ı planlama aşamasinda aile katılm sürecine yer veriyor musunuq? Evet, ise Ne tür aile katıllm etkinlikleri planlyyorsunuq?" şeklindeki sorular sorulmuştur. Öğretmen adaylarının öz-yeterlik puanlarının düzeyinden bağımsız bir şekilde, aile katılımı etkinliklerine dâhil edilmeleri konusunda bariyer ve sımrllhklarla karşılaştıklarından bahsetmişlerdir. Özetle, aile katılımı etkinliklerinin içeriğine yönelik kavramsallaştırmaların öğretmen veya öğretmen adayı olma durumu ve öz-yeterlik düzeyine göre farklılaştığı söylenebilir.

$\ddot{\boldsymbol{O}} \boldsymbol{A}_{\text {2üst }}$ : Bizler öğretmen adayı olduğumuz için aileler ile birebir görüşme yapmamıza izin verilmiyor. Belki bu noktada önümüzü açsalar daha da fazlasını yapabiliriz. Böyle olunca kısıtlanıyoruz.

$\boldsymbol{O}_{\boldsymbol{A}_{3} \text { alt: }}$ Uygulamaya gittiğim okulda aile katılımı için belirlenmiş bir gün var zaten o yüzden benim uygulama günümde buna yer verme şansım olmuyor. Doğal olarak da aile katılımı konusunda sınırlanmış oluyorum. Zaten aile ile bire bir de iletişim yürütmemize izin verilmediği için aile katılımına yer veremiyorum.

\section{Ögrretmen Yeterliği}

Katılımcıların aile katılımı etkinliklerini gerçekleştirme konusunda kendilerini yeterli görüp görmediklerini belirleme amacıyla alt ve üst gruptaki öğretmenlere “Aile katılımm etkili bir sekkilde gerçekleștirebildiğiniz̨i düsünüyor musunuz? Neden?’ şeklinde soru yöneltilmiştir. Tümevarımsal içerik analizi sonucu üst grupta yer alan öğretmenler kendilerini yeterli, alt grupta yer alan öğretmenler ise kendilerini yetersiz gördüklerini belirtmişlerdir.

$\ddot{\boldsymbol{O}}_{1 u ̈ s t}$ : Evet, gerçekleştirebildiğimi düşünüyorum. Broşürle gerçekleştirilebileceğine inanmiyorum. Ben ailelerle birebir görüştüğümde onları ikna edebilirim. Birebir karşına alıp bu konuda bu şekilde davranırsan böyle olur şeklinde konuştuğumda ailenin aklında bu konu anlaşılır. Ve dönem başı ve dönem sonu olarak yaparım demiştim ve böyle sık sık da bunları kontrol edersen veliyle birebir o zaman etkili olur. Ve mantıklı olan da bu.

$\ddot{\boldsymbol{O}}_{3 a l t}$ : Çok nadir olduğunu düşünüyorum. Çünkü veliler etkinlik yaparken bir yerden sonra sıkıllyor ses ve gürültü oluyor diye. O yüzden çocuklar vakit geçirmeyi seven çok nadir velilerle aile katılımın etkili bir şekilde yürütebiliyoruz.

Aileleri, okul öncesi öğretim etkinliklerine dâhil etme konusunda kendini yeterli gören öğretmen bunun nedeni olarak sosyal etkileşim ve iletişimsel süreglere atıf yapmıştır. Kendini bu tür etkinlikler için yetersiz gören alt gruptaki öğretmenin de aynı şekilde sosyal etkileşim ve iletişimsel süreçlerden bahsettiği ve aile ile sağlıkı bir iletişim kuramadığı için aile katılımı etkinliklerinin sekteye uğradığına vurgu 
yaptığ1 tespit edilmiştir. Dolayısıyla aile katılımına yönelik öz-yeterlik bağlamında yapılan açıklamaların ortak bir atıfsal akıl yürütmeden beslendiği söylenebilir. Aile katılımına yönelik özyeterlik bağlamında öğretmen adaylarının verdiği yanıtlarda da aynı şekilde üst grupta yer alan öğretmen adayları kendilerini yeterli, alt grupta yer alan öğretmen adayları ise kendilerini yetersiz gördükleri ortaya çıkmıştır.

$\ddot{\boldsymbol{O}} \boldsymbol{A}_{\text {1üst }}$ :Ĕger aile yapısı ve görev yaptığım kurum uygun olursa aile katılımını etkili bir şekilde gerçekleştirebileceğimi düşünüyorum. Her şeyden önce bu konuda iletişim yeteneğime güveniyorum.

$\ddot{\boldsymbol{O}} \boldsymbol{A}_{1 a l t}: H a y ı r$, bunun sebebi ise öğretmen olduğumda bütün aileleri aile katıllımına katılım sağlayacaklarını düşünmüyorum. Çünkü bütün aileler farklı örnek olarak eve broşür, mektup tarzı bir uygulama gönderdiğimde çoğu ailelerin okumayacaklarını düşünüyorum. Evet eğitimlerde bu şekilde anlatıllyor ancak sahada çalşısıken uygulamada böyle olduğunu düşünmüyorum. Kendimi de bu konuda yeterli hissetmiyorum zaten. Çünkü ön bir hazırlığım ya da sürece dair gözlem yapma şansım olmadı hiç. Bu sebeple de sanırım bu süreci düşe kalka öğreneceğim.

\section{Olumlu ve Olumsuz Durumlar}

Alt ve üst gruptaki öğretmenlerin aile katılımı etkinlikleri sırasında karşılaştıkları olumlu ve olumsuz

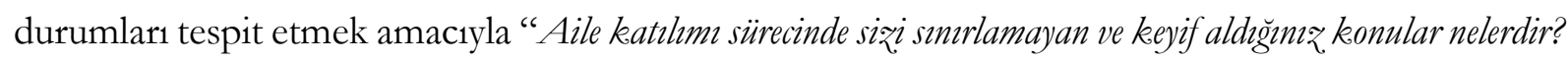
Aile katılım sürecinde siz̨i zorlayan/sinırlayan konular var ise bunlar nelerdir? Aile katılimmda yaşamıs olduğunuz olumlu ve olumsuz durumlar anlatır mosinız? Yaşamıs olduğunuz olumsuz durumlarda engellerin üstesinden gelmek için nasıl bir yol iə̌lemişstiniz̨?" ş̧eklinde sorular yöneltilmiştir. Öğretmenlerin genel olarak olumsuz durumlara değindikleri görülmektedir.

$\ddot{O}_{\text {2üst: }}$ Bireysel yaptığım görüşmelere katılmayan veliler beni sınırlandırıyorlar. Görüşmede beni dinlemeyen anlık geçiştiren veliler çok etkiliyor. Bir veli görüşmesinde çocuğun durumu anlattığımda çözüm için fikir söylediğimde veliden tepki olarak "hayır benim çocuğum paşadır. Benim çocuğum bu şekilde davranır sizde bu şekilde idare etmek zorundasınız" şeklinde bir cevap almıştım. Olumsuz tepki almıştım. Bu durum beni psikolojik olarak beni çok etkilemişti. Daha sonrasında veliye herkesin çocuğunun çok değerli olduğunu ve benimde onlara çok değer verdiğimi söylemiştim. Çocuğunuza değer verdiğim için onun için en iyisini istiyorum şeklinde konuşmaya başladım.

$\ddot{O}_{3 a l t:}$ Yaptığımız etkinlikte ailelerin benim üzerimde sürekli bir eksik aramaları, çocuklar arasında ayrımcılık yaptığımı düşünmeleri beni olumsuz etkiliyor. Bu olumsuz durumların üstesinden gelebilmek için ailelere durumu açıklıyoruz. Bazı velilerimiz anlayamaya biliyor. Bu durum karşısında maalesef herhangi bir şey yapamıyoruz. Karşınızdaki insan iletişime kapalı olunca belli bir nokta da siz de kilitleniyorsunuz. Söylediğim gibi her veli çocuğuna özel bir muamele istiyor. Aile katılımı için etkinlik yaptırmaya geldiğinde istiyor ki çocuğuna ayrıcalıklı davranılsın, şımartılsın öyle bir durumda söz konusu olamaz tabi doğal olarak bir çatışmaya giriyoruz. Bende belli bir noktadan sonra yoruluyorum. 
Aile katılımı etkinliklerine staj uygulamaları bağlamında katılım gösteren öğretmen adaylarının açıklamalarına bakıldığında ise onların da genel anlamda olumsuz durumlara atıf yaptıkları görülmüştür. Fakat alt ve üst gruptaki öğretmen adayları farklı olumsuz durumlardan bahsetmişlerdir.

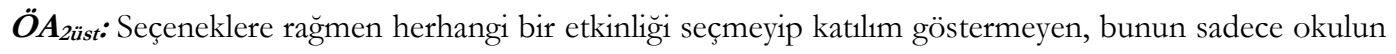
görevi olduğunu düşünen aileler beni zorluyor. Sadece uygulamaya gittiğim için aileleri tanımıyorum ve bazıları ne yazık ki farklı konularda sorun yaşadıkları için okul ile iş birliğine uzaklar. Bu sebeple katılım göstermiyorlar.

$\ddot{\boldsymbol{O}} \boldsymbol{A}_{\text {lalt }}$ : Stajyer olduğum için öğretmenim aile ile iletişime geçmemde sıkıntı yaratmıştı. Aslında gördüğüm derslerde aile katılımının çok zor olmadığını öğrenmiştim. İlk başladığımda çok korkmuştum, fakat aile ile sohbet edilmesi bile aile katılımı olduğunu öğrendiğim günden beri bu işi için hevesliydim ancak öğretmenden kaynaklı uygulama yapamadım.

Üst gruptaki öğretmen adayının karşılaştığı olumsuz durumlarla ilgili aile kaynaklı bariyerlere, alt gruptaki öğretmen adayının ise öğretmen kaynaklı bariyerlere atıf yaptıkları görülmüştür.

\section{Niteliği Artturma Stratejileri}

Öğretmen ve öğretmen adaylarının aile katılımı etkinlikleri ile ilgili görüşlerine başvurulan son veri kaynağı, niteliği arttırma stratejileri ile ilgilidir. Bu amaç doğrultusunda alt ve üst gruptaki tüm katılımcılara "Aile katılımm arttırmak adına nasıl bir uygulama/strateji gelistirirsiniz?" şeklindeki soru yöneltilmiştir. Buna göre üst gruptaki öğretmenler aile katılımını arttırmak için sosyal etkileşim ve katılım genişletme ile ilgili stratejiler, alt gruptaki öğretmenler ise yetişkin ve ögretmen eğitimi süreçlerine dikkat çekmişlerdir.

$\ddot{\boldsymbol{O}}_{\text {lüst}}$ : Ailelerin katılımını arttırmak için programı onlara göre ayarlamaya çalışıyorum. Yani çok emri vaki şeklinde değil de onlara seçenek sunarak ilerliyorum. Siz hangi gün müsait olursunuz? Nasıl ilerleyelim? şeklinde iletişime geçiyorum. Böylece velilerim kendilerini zorunlu hissetmiyor. Evde görüşme saatleri ayarlamaya çalş̧yorum. Aileleri ve çocukları kendi ortamlarından gözlemleye bilmek için bu durumda aileye kendisini değerli hissettiriyor. Yine ailelerin müsait olma durumuna göre onları okula davet ediyorum. Zaten onlarda okula geldiğinde çocuklarının mutluluğunu görünce iyi ki çağırmışsınız hocam diyorlar. Süreci yönetirken ailelere seçenek sunmak onların katılımını destekliyor.

$\ddot{\boldsymbol{O}}_{2 a l t}$ : Aile katılımı için öncelikle öğretmenlik bölümünde değişiklikler yapılması gerektiğini düşünüyorum. İlk öğretmeni olarak gördüğümüz aile bu kadar önemli iken üniversitedeler de buna biraz daha özen gösterilmeli. Artık göreve başlayan öğretmenler için de kendilerini geliştirmek adına hizmet içi eğitimlerde bunlara sıkça yer verilmeli. Bu eğitimlerde örnek olaylar, aileler göz önünde bulundurularak canlandırmalar yapılarak problem çözme ve çözüm üretme konusunda beceriler geliştirilebilir. Bu şekilde de öğretmen sahada karşısına çıkan sorunlarda korkup göz ardı etmek yerine 
daha cesur davranıp çözüm üretebilir. Hatta çözüm üretemediği sorunlarda danışabileceği bir telefon hattı veya bir birim oluşturulabilir. Öğretmenleri aile katılımına teşvik etmek ve yardımda bulunmak için her şehirde bir birim kurulabilir. Farklı aile katılım çalışmalarının sergilendiği, ailelerinde içinde bulunduğu bir birim olsa öğretmenler de kendini yalnız hissetmezler. Ve tabi sadece öğretmen ve öğretmen adaylarına yönelik eğitimler değil ailelere yönelik eğitimlerde mutlaka yapılmalı ve zorunlu olmalı diye düşünüyorum.

Örnek açıklamalarda da görülebileceği üzere üst gruptaki öğretmenin iletişim engelini kaldırmak adına ev ziyaretleri gibi sosyal etkileşimi arttıracak stratejiler kullandığı belirlenmiştir. Diğer yandan alt gruptaki öğretmenin özellikle hizmet içi ve öncesi eğitim süreçlerinin daha fazla zenginleştirilmesi gerektiğine değindiği görülmüsstür. Alt ve üst gruptaki öğretmen adaylarının bu soruya verdikleri yanıtlara bakıldığında ise öz-yeterlik puanlarının düzeylerinden bağımsız olarak aynı temalara atıf yaptıkları görülmüştür.

$\ddot{O} \boldsymbol{A}_{3 \ddot{3} \text { st: }}$ : Her ailenin farklı olduğunu biliyorum. Her aile çocuğu için en iyisini ister. Ancak onlara sunulan katılım etkinliği sınırlı olursa, aile bunu neden yapması gerektiğine dair bilgilendirilmezse ve farklı açılardan (maddi-manevi) uygun olmazsa gerçekleşemez. Aileleri tanıdıktan sonra uygun olan ve farklı seçenekler halinde sunulan etkinliklere yer verip, bu etkinliğin ne gibi nedenlerle yapılacağını ve sonuçlarında ne gibi kazanımlar elde edebilecekleri konusunda bilgilendirip, geri dönüşlere göre değiştirip çeşitlendirme stratejisi geliştirebilirim. Onların da öğrenecekleri ortamları onlarla birlikte oluşturmaya özen gösteririm.

$\boldsymbol{O}_{\boldsymbol{A}_{3 a l t}}$ Ev ziyareti kapsamında uygulamalar yaparım. Çünkü kendi ev ortamında gördüğüm için ve aile ortamını da birebir gördügüm için çocukla ilgili empati kurmam daha kolay olur.Nasıl bir ortamda yaşadığını görerek daha düzenli bireysel ona göre bir program yapılabilir diye düşünüyorum. Velilerin çocukları okula bırakmaya ve almaya geldikleri vakitlerde onlarla konuşmaya özen göstermeye çalışırım onlara yapabilecekleri etkinlikler konusunda fikirler verebilirim, örnek olarak veli ev hanımı ise anne bir kek yapmasını basitleştirerek resimle bunu anlatabilir böylelikle beraber bir proje yapmış olurlar ve ailelerinde korkuları yenilmiş olur bu şekilde.

\section{SONUÇ ve TARTIŞMA}

Bu araştırmada Aile Katılımı Öz-Yeterliği Değerlendirme Ölçeği ve yarı-yapılandırılmış görüşmeler neticesinde okul öncesi öğretmen ve öğretmen adaylarının aile katılımına yönelik öz-yeterlik inançları incelenmeye çalışılmıştır. Çünkü ulusal ve uluslararası çalışmalar incelendiğinde okul öncesi öğretmen ve öğretmen adaylarının aile katılımına yönelik öz-yeterlik inançlarını bir arada inceleyen bir çalışmaya rastlanılmamıştır. Araştırmanın karma yöntem ile gerçekleştirilmiş olmasının da literatür açısından önem arz ettiği düşünülmektedir. Nicel verilerin analiz sonuçlarına bakıldığında okul öncesi öğretmen ve öğretmen adaylarının aile katılımına yönelik öz-yeterlik inançlarının kıdem, yaş ve aile katılımına yönelik eğitim alıp almadıklarına göre anlamlı bir şekilde 
farklılaşmadığı tespit edilmiştir. Fakat kıdem yılı fazla olan öğretmenlerin aile katılımına yönelik özyeterlik inançlarında daha yüksek bir ortalamaya sahip oldukları saptanmıştır. Atabey (2008) gerçekleştirdiği çalışmasında öğretmenlerin aileler ile olan ilişkilerinin yaş gruplarına, öğrenim durumlarına, mesleki kıdemlerine, anne baba eğitimi ile ilgili ders alma durumlarına göre istatistiksel olarak anlamlı olduğunu saptamıştır. Bu durumda öğretmenlerin kıdem durumlarının aile katılımına yönelik bakış açılarını etkilediğini ortaya çıkarmaktadır.

Araştırma bağlamında bulguların analizi sonucunda okul öncesi öğretmen ve öğretmen adaylarının aile katılımına yönelik öz-yeterlik inançları arasında anlamlı bir farklılaşma saptanmıştır. Öğretmen ve öğretmen adaylarının nicel veri analizlerinden elde edilen bulgular sonucunda aile katılımına yönelik öz-yeterlik inançlarında farklılık tespit edilse de nitel verilerin analizinde elde edilen bulgular öğretmen ve öğretmen adaylarını ortak paydada buluşturarak aile katılımını önemli gördüklerini ortaya çıkarmıştır ve her iki grupta sosyal etkileşime atıf yapmıştır. Anthony'nin (2008) çalışması öğretmenler ve aileler arasında iletişimsizlikten kaynaklanan yanlış anlaşılmaların ailelerin okula yönelik ilgi yetersizliğine sebep olduğunu ortaya koymuştur. Bu sonuç kapsamında okul öncesinde gerçekleştirilen aile katılımı çalışmalarının öğretmen ve aile arasında köprü kurarak iletişimi arttıracağını, sosyal etkileşimin sağlanacağını ve ailelerin bu çalışmalar sayesinde ilköğretim döneminde daha tecrübeli olacağı sonuçlarını düşündürmektedir. Bu bağlamda Anthony'nin (2008) çalışması araştırmadan elde edilen sonuçları destekler niteliktedir. Okul öncesi öğretmen ve öğretmen adaylarının öz-yeterlik puanlarının düzeyi dikkate alındığında ise puanlarının aile katılımı hakkındaki kavramsallaştırmalarında görünür bir farklılaşmaya neden olmadığı tespit edilmiştir. Öğretmen yeterliği kapsamında öğretmenler sosyal etkileşim ve iletişim süreçlerine atıf yaparlarken, üst grupta yer alan öğretmen adayları iletişim yeteneğinden kaynaklı kendilerini aile katılımı konusunda yeterli gördüklerini belirtmişlerdir. Bu bağlamda öğretmen ve öğretmen adaylarının ortak paydada buluştukları görülmektedir. Her iki grubunda yeterli hissetme düzeyinde öncelikle iletişim süreçlerine atıf yaptıkları söylenebilir. Cheung, (2008) öğretmen öz-yeterliği ile ilgili gerçekleştirmiş olduğu çalışmada öğretmenlerin öz-yeterliklerini etkileyen üç faktöre ulaşmıştır. Bunlar öncelikle ailelerin ve çocukların öğretmenlere duydukları sayg1 ve güvendir. Daha sonra ise lisans eğitimleri ve öğretmenlik uygulamalanından elde ettikleri deneyimleridir. Araştırma kapsamında öğretmen ve öğretmen adayları aile katılımında karşılaştıkları olumsuz durumların aile kaynaklı sıkıntılardan dolayı yaşandığına atıf yapmışlardır. Bu durumda her iki grubu ortak noktada buluşturmuştur ve iletişim sürecine değindikleri tespit edilmiştir.

Whyte ve Karabon (2016) gerçekleştirdikleri çalışmada okul öncesi öğretmenlerinin okul-aile iş birliğine ilişkin geleneksel roller yerine modern rollerin desteklenmesinin sonucunda öğretmenlerin 
aile katılım çalışmalarını daha etkili bir şekilde gerçekleştirdikleri sonucuna ulaşmıştır. Araştırma kapsamında öğretmenler aile katılımına yönelik etkinliklere sınırlı kapsamda yer verdiklerini belirtmişlerdir. Öğretmen adayları ise uygulamaya gittikleri okullarda etkinliklere dahil edilme konusunda bariyer ve sınırlılıklarla karşılaştıklarını belirtmişlerdir. Ayrıca aile katılımına yönelik etkinliklerde sınırlı bakış açısına sahip oldukları saptanmıştır. Ajanga, (2011) okul öncesi öğretmen adaylarının aile katılımına yönelik öz-yeterlik inançlarını incelediği çalışmasında öğretmen adaylarının inanç düzeylerinin orta düzeyde olduğunu saptamıştır. Öğretmen adaylarının yeterlik inançlarının, kişisel gelişimlerini, eğitim anlatımlarını ve diğer çalışmalarını etkilediği ortaya çıkmıştır. Bu kapsamda öz-yeterlik inancı düşük olan öğretmenler çocukların performanslarına olumlu kazanımlar sağlayabileceklerine ve eğitim kapsamında etkili bir ebeveyn iletişimi kurabileceklerine inanmazlar. Fakat çocukların eğitiminde etkili ve uzun süreli olumlu kazanımlara sahip olabilmenin sırrı aile ve eğitimci arasındaki başarılı ilişkilerdir (Kayır, 2015). Araştırmada yer alan üst ve alt grup öğretmen adayları lisans eğitimlerinde gördükleri aile katılımı ile ilgili eğitimin teorik açıdan baskın olmasına atıf yapmışlardır. İki grup da uygulamalı derslerin artırılması konusunda öneride bulunmuştur. Öğretmen adayları henüz mesleğe başlamadıkları için aile katılımı konusunda neler yapabileceklerini de öngörememektedirler. Mesleki deneyime sahip olmayan öğretmen adaylarının bilgileri sadece teoride kalmaktadır. Öğretmen adaylarının mesleğe başlamadan önce henüz lisans eğitimde iken aile katılımına yönelik daha fazla deneyim edinmeleri gerektiğini söyleyen çalışmalar literatürde mevcuttur. Bu durumda öğretmen adaylarının uygulamalı derslere yapmış olduğu atıfı destekler niteliktedir (Örn; Tschannen-Moran ve Woolfolk-Hoy, 2007; Uludağ, 2008; Fry, 2009; Walker ve Dotger, 2012; Cevher-Kalburan, 2014).

Öğretmen ve öğretmen adayları aile katılımı konusunda ortak paydada sosyal etkileşime atıf yapmışlardır. Bu bağlamda öğretmen adaylarının sosyal etkileşim sağlayabilmelerini desteklemek gerekmektedir. Uygulamaya gittikleri okulda aile katılım çalışmaları yapmalarına, aileler ile iletişim kurmalarına, karşılaştıkları problemlere çözüm yolları üretmelerine olanak tanınmalıdır. Böylelikle öğretmen olarak göreve başladıklarında aile katılımı sürecini yönetirken öngörüleri kuvvetli olacak ve kayg1 düzeyleri en aza inecektir. Literatürde aile katılımına yönelik öz-yeterlik inançları kapsamında öğretmen ve öğretmen adayları ile gerçekleştirilen çalışmaların arttırılmasının, öğretmenler ve henüz mesleğe başlamamış öğretmen adayları için yol gösterici olacağ1 düşünülmektedir. Ailelerle iyi bir iletişim kurabilmek öğretmenlik mesleğinin merkezinde yer alan bir konudur. Bu sebeple de öğretmenlik eğitimi veren kurumlar öğretmen adaylarını bu konuda desteklemelidirler. Öğretmen adaylarına okul-aile iş birliği konusunda yeterli bilgi, beceri ve tutumlarını geliştirebilmeleri kapsamında yardımcı olmalı ve onları iş birliğine hazırlamalıdırlar (Walker ve Dotger, 2012). 
Kök, Çiftçi ve Ayık (2011) tarafindan gerçekleştirilen çalışmada okul öncesi öğretmen adaylarının aileler ile iletissim, aile katılımı ve aile eğitimi boyutlarında düşük bir ortalamaya sahip oldukları sonucunu elde etmişlerdir. Öğretmenlerin yaşamış oldukları olumlu ve olumsuz durumlar karşısında doğru tespitler yapabilmeleri onların yeterlik inançlarının güçlenmesini sağlayacaktır. Öğretmenler başarılarını içsel nedenlere yani başarı ve yetenek gibi durumlara yüklüyorlarsa bu onların öz-yeterlik inançlarını geliştirecektir. Ancak öğretmenler başarılı olma veya başarısız olma durumlarını başka kişilerin müdahalelerine yüklerler ise öz-yeterlik inançları bundan olumsuz etkilenecektir (Goddard, Hoy ve Hoy, 2004). Bu bağlamda araştırmadan elde edilen sonuçlarda da öğretmen ve öğretmen adaylarının öz-yeterlik inançlarının yeterliliğinde iletişimsel süreçlere ve hem aileden kaynaklı hem de hizmet öncesi eğitimin yetersizliğinden kaynaklı durumlarla ilişkilendirdikleri görülmüş, kendilerinden kaynaklı herhangi bir sebepten bahsetmedikleri saptanmıştır. Öğretmenlerin yüksek öz-yeterlik inançlarına sahip olabilmesi için lisans eğitimlerinde de desteklenmeleri, bilgi akışının sağlanması gerekmektedir. Lisans eğitimleri sayesinde öğretmen adayları alanda tecrübe edinebileceklerdir. Bu bağlamda lisans ve yüksek lisans programları öğretmen adaylarının mesleki öz-yeterliklerini güçlendirmek üzerine stratejiler geliştirmelidirler. Öğretmen adayları uygulamalı eğitimlerle eğitimsel becerilerini, iletişim stratejilerini geliştirirler (Pechackova ve vd., 2015).

Aile katılımının temel amacı aileleri eğitimin bir parçası olacak şekilde sürece dahil edebilmektir. Bu sürecinde aileler, öğretmen ve kurum tarafindan tutarlı ve devamlı bir şekilde sürdürülmesi sağlanmalıdır. Bu süreçte de aileler ile de iyi bir ilişki kurmak için etkili iletişim kurabilmek gerekmektedir. Öğretmenler ve aileler arasındaki iletişim ise bilgi paylaşımından daha fazlasını ifade etmekte ve gerektirmektedir (Alaçam, 2015). Marchini'nin (2011) araştırmasından elde ettiği sonuçlara göre aile katılımı konusunda olumlu tutumlara sahip olan öğretmenlerin sınıflarında aile katılımına daha fazla yer verdiklerini ortaya çıkmıştır. Ayrıca aile katılımı uygulamaları konusunda okul yönetiminin daha fazla destek verdiği kurumlardaki öğretmenlerin aile katılımına yönelik olumlu tutum geliştirdikleri ve çalışmalara yer verdiklerini saptamıştır. Araştırma kapsamında elde edilen bir diğer sonuç da öğretmenlerin aile katılımına ilişkin bakış açılarının mesleki yeterlilikleri ile bağlantılı olmasıdır. Okul öncesi öğretmenlerin aile katılımına yönelik değindikleri en önemli nokta sosyal etkileşimdir. Bu bağlamda kurumlarda öğretmen ve aile arasındaki sosyal etkileşimi arttırmaya yönelik çalışmaların gerçekleştirilmesi büyük önem arz etmektedir. Öğretmen adaylarının da aile katılım sürecine hazır olabilmeleri için lisans eğitiminde daha çok uygulama ağırlıklı eğitimler almaları ve deneyim kazanmaları gerekmektedir. Araştırma verilerinden elde edilen sonuçlar literatür ile desteklenmiştir. Bu bağlamda aile katılımına yönelik öz-yeterlik inançları ile ilgili öğretmenler ile gerçekleştirilen çalışmalarda sınırlılık olduğu saptanmış ve bu başlıkta öğretmen 
adayları ile gerçekleştirilen sınırlı sayıdaki çalışmalara rastlanılmıştır (Ateş, 2015; Alaçam, 2015). Bu kapsamda aile katılımı konusunda öğretmen adayları ve öğretmenler ile daha fazla çalışılma gerçekleştirilmesi ve öz-yeterlik inançlarını geliştirebilmek, öğretmen adaylarını mesleğe hazırlayabilmek adına örnek çalışmaların yapılması ayrıca önerilerin arttırılması gerekliliği ortaya çıkmaktadır. Araştırmada ulaşılan bu sonuçlar doğrultusunda şu öneriler verilebilir:

1. Aile katılımı süreçlerinin kalitesini arttırmak adına izlenebilecek yolları ele alan çalışmaların sayısı arttırilabilir.

2. Öğretmenlerin ve öğretmen adaylarının aile katılımı ile ilgili bariyer algılarını, öz-yeterlik inançlarını, süreci yönetebilme kabiliyetlerini geliştirecek çalışmalar gerçekleştirilebilir.

3. Aile katılımına yönelik öz-yeterlik inançlarını geliştirecek kapsamda öğretmen ve öğretmen adaylarıyla birlikte çalışmaların sayısı arttırılabilir.

4. Okul öncesi sınıflarında öğrencilere zengin öğrenme ortamı sunmak için aile katılımına daha fazla önem verilebilir.

5. Eğitimde niteliği arttırmak adına aileler ile sosyal etkileşimin artması yönünde katkı sağlayacak çalışmaların sayısı arttırılabilir.

6. Öğretmen adaylarının staj uygulamalarında aile katılımı ile ilgili etkinliklerin yer aldığ1 süreçlere dahil olmaları konusunda daha fazla desteklenmeleri sağlanabilir.

7. Aile katılımı süreçlerini planlamak, yürütebilmek ve gerekli öz-yeterlik inançlarının gelişebilmesi için öğretmen adaylarının bu süreçlere aşina olmaları ve pedagojik becerilerinin gelişmesi için etkin rol alabilecekleri öğrenme ortamları arttırılabilir.

8. Hizmet içinde yer alan aile katılımı derslerinin uygulama ağıllkklı olması sağlanarak, öğrenmelerin kalıcı olması desteklenebilir.

9. Lisans ve Lisansüstü programlarda aile katılımı ile ilgili çalışmalar farklı derslere entegre edilerek öğretmen adaylarının aile katılımı ile ilgili bakış açılarının geliştirilmesi desteklenebilir.

\section{KAYNAKÇA}

Ajanga, A. J. (2011). Teachers perception, beliefs, and self-efficacy about parental engagement and school family partnerships in kenya. Yayımlanmamıs Doktora tezi, USA: Texas Woman's University, Department Of Family Sciences College Of Professional Education, USA.

Alaçam, N. (2015). Ögrretmen adaylarmm aile katılimma yönelik öz-yeterlik inançlarmm genel öz-yeterlik inançlar ve aile katılımına yönelike bariyer algılar ile ilişkilendirilmesi. Yayımlanmamış Yüksek Lisans Tezi,Orta Doğu Teknik Üniversitesi, Sosyal Bilimler Enstitüsü, Ankara. 
Anthony, C. M. (2008). Parental involvement: an examination of barriers, perceptions, and strategies that effect the relationship between parent and school. Yayımlanmamıs Doktora Tezi, Walden University, College Of Education, USA.

Atabey, D. (2008). Yönetici ögretmen aile iletişsim ve işbirlï̆i aracı geçerlik güvenirlik çallsmasi ve okul öncesi eğitim kurumlarndaki yönetici, ögretmenler ile aileler arasindaki iletisim ve işbirlï̈inin yönetici, ögretmen, aile bakıış açısına göre incelenmesi. Yayımlanmış Yüksek Lisans Tezi, Gazi Üniversitesi, Eğitim Bilimleri Enstitüsü, Ankara.

Ateş, Ö. (2015). Okul öncesi ögretmen adaylarmm aile katılım çalışmalarnna yönelik öz-yeterlik inançlarnnn incelenmesi. Yayımlanmamış Yüksek Lisans Tezi, Pamukkale Üniversitesi, Eğitim Bilimleri Enstitüsü, Denizli.

Ay, B. (2007). Öğretmenlerin öz-yeterlikleri ve örgütsel vatandaşllk. davranışı. Yayımlanmamış Yüksek Lisans Tezi, Afyon Kocatepe Üniversitesi, Sosyal Bilimler Enstitüsü, Afyon.

Baum, A. C. ve McMurray Schwarz, P. (2004). Preservices teachers beliefs about family involvement: implications for teacher education, Early Childhood Education Journal, 32(1), 5761.

Biber, K. (2018). Öğretmen adaylarının aile katılımına ilişkin öz yeterlilik inanç düzeylerinin belirlemesi. Türkiye Sosyal Arastırmalar Dergisi, 22(2), 623-642.

Bulut Üner, A. N. (2018). Okul öncesi ögretmen adaylarmm bilimsel süreç becerileri, fen ve matematik ögretimine yönelik tutumlar ve öz yeterlik inançlar arasındaki ilişki. Yayımlanmamış Yüksek Lisans Tezi, Dokuz Eylül Üniversitesi,Eğitim Bilimleri Enstitüsü, İzmir

Büyüköztürk, Ş. (2012). Sosyal Bilimler İ̧in Veri Analiz̧i El Kitabı. (16. Baskı) Ankara: Pegem Yayinc1lik.

Büyükyıldırım, S. (2018). Okul öncesi ögretmenleri ve okul öncesi ögretmen adaylarnmn görsel sanatlar öz yeterlik. algılar. Yayımlanmamıs Yüksek Lisans Tezi,Gazi Üniversitesi, Eğitim Bilimleri Enstitüsü, Ankara.

Cevher Kalburan, N. F. (2014). Early childhood pre-service teachers' concerns and solutions to overcome them (the case of pamukkale university). South African Journal of Education, 34(1), 118.

Cheung, H. Y. (2008). Teacher efficacy: a comparative study of hong kong and shanghai primary in-service teachers. The Australian Educational Researcher, 35(1), 103-123.

Creswell, J. W., Shope, R., Plano Clark, V. L. ve Green, D. O. (2006). How interpretive qualitative research extends mixed methods research. Research in The Schools, 13(1), 1-11.

Çetinkaya, H. (2017). Okul öncesi eğitim kurumuna devam eden 4-6 yas grubu cocuklarn annelerine yönelik bir aile katılımı programı önerisi. Yayımlanmamıs Yüksek Lisans Tezi,Ankara Üniversitesi, Ĕ̈itim Bilimleri Enstitüsü, Ankara.

Dönmez, Ö. ve Ramazan, O. (2017). Okul öncesi öğretmen adaylarının aile katılımına yönelik tutumları ile öz yeterlilik inançları arasındaki ilişkinin incelenmesi. Yuldı . Sosyal Bilimler Enstitüsü Dergisi, 1(1), 29-45. 
Erdoğan, Ç. ve Demirkasımoğlu, N. (2010). Ailelerin eğitim sürecine katılımına ilişkin öğretmen ve yönetici görüşleri. Kuram ve Uygulamada Eğitim Yönetimi, 16(3), 399-431.

Fry, S. W. (2009). Characteristics and experiences that contribute to novice elementary teachers' success and efficacy. Teacher Education Quarterly, 36(2), 95-110.

Garcia, D.C. (2004). Exploring connections between the construct of teacher efficacy and family involvement practices: implications for urban teacher preparation. Urban Education, 39(3), 290-315.

Garvis, S. ve Pendergast, D. (2011). An investigation of early childhood teacher self-efficacy beliefs in the teaching of arts education, International Journalof Education \& The Arts, 12(9), 1-16.

Giannakaki, M. S. (2005). Using mixed-methods to examine teachers' attitudes to educational change: the case of the skills for life strategy for improving adult literacy and numeracy skills in england. Educational Research and Evaluation, 11(4), 323-348.

Goddard, R. D., Hoy, W. K., ve Hoy, A. W. (2004). Collective efficacy beliefs: theoretical developments, empirical evidence, and future directions. Educational Researcher, 33(3), 3-13.

Gökyer, N. (2017). Okulöncesi öğretmenlerinin uyguladıklar1 aile katılım stratejileri. İnönü Üniversitesi Ë̈̈tim Fakültesi Dergisi,18(3), 334-348.

Gömleksiz, M. N. ve Serhatoğlu, B. (2013). Okul öncesi öğretmenlerinin öz-yeterlik inançlarına ilişkin görüssleri. International Periodical For The Languages, Literature and History of Turkish or Turkic, 8(7), 201-221.

Guo, Y., Justice, L. M., Sawyer, B. ve Tompkins, V. (2011). Exploring factors related to preschool teachers' self-efficacy.Teaching and Teacher Education, 27(5), 961 - 968.

Gürbüztürk, O. ve Çalış, N. (2019). The problems of preschool teacher candidates facing in teaching practice. Inonu University Journal of the Graduate School of Education, 6(12), 108-122.

Kayır, G. (2015). Okul öncesi eğitimde reggio emilia yaklaşımından esinlenerek yapılan proje çalışmaları: bir eylem araştırması. Yayımlanmamış Yüksek Lisans Tezi, Dumlupınar Üniversitesi, Eğitim Bilimleri Enstitüsü, Kütahya.

Koç, F. (2015). Okul öncesi ögretmenlerinin okul öncesi eğitim programmdaki etkinliklere yönelik öz-yeterlik inançlarmın incelenmesi. Yayımlanmamış Yüksek Lisans Tezi, Van Yüzüncü Yıl Üniversitesi, Eğitim Bilimleri Enstitüsü, Van.

Kök, M., Çiftçi, M. ve Ayık, A. (2011). Öğretmenlik mesleği özel alan yeterliklerine ilişkin bir inceleme (okul öncesi öğretmenliği örneği). Atatürk Üniversitesi Sosyal Bilimler Enstitüsü Dergisi, 15(1), 169-183.

Krizman, C. (2013). The relationship between teachers self-efficacy beliefs and parental involvement practices: a multi-method study. Yayımlanmamış Doktora Tezi, Texas Tech University, Educatıonal Psychology, USA. 
Latipov, Z. A., Bykova, S. S. ve Zhigalova, M. P. (2016). The family club activities for organizing a social partnership of the pre-school educational institution and the family. International Journal Of Environmentales Science Education, 11(5), 655-662.

Marchini, L. (2011). Teacher and school variables that impact special education preschool teacherfamily involvement behaviors. Yayımlanmamış Yüksek Lisans Tezi, The City University Of New York, Educational Psychology, New York.

Morrison, J. W., Storey, P. ve Zhang, C. (2015). Accessible family involvement in early childhood programs. Dimensions of Early Childhood, 39(3), 21-26.

Neuman, W. L. (2012). Toplumsal Araștırma Yöntemleri: Nicel ve Nitel Yaklaşımlar. (5. Baskı) İstanbul: Yayin Odas1.

Shenton, A. K. (2004). Strategies for ensuring trustworthiness in qualitative research projects. Education For Information, 22(2), 63-75.

Skaalvik, E. M. ve Skaalvik, S. (2010). Teacher self-efficacy and teacher burnout: a study of relations. Teaching and Teacher Education, 26(4), 1059-1069.

Stuckey, A. (2010). Influences of an overlapping goal-setting strategy on the personal standards and efficacy toward parent involvement in education for pre-service teachers. Yayımlanmamış Doktora Tezi, Northern Illinois University, Department of Leadership, Educational Psychology and Foundations, USA.

Şenol Ulu, F. B. (2012). Okul öncesi ögretmen adaylar ile okul öncesi ögretmenlerinin ögretmenlik mesleğine yönelik öz, yeterlik inançlarmın karşılaștırlması. Yayımlanmamış Yüksek Lisans Tezi, Afyon Kocatepe Üniversitesi, Sosyal Bilimler Enstitüsü, Afyon.

Tschannen Moran, M. ve Woolfolk Hoy, A. (2001). Teacher efficacy: capturing an elusive construct. Teaching and Teacher Education, 17(7), 783-805.

Uludağ, A. (2008). Elementary preservice teachers' opinions about parental involvement in elementary children's education. Teaching and Teacher Education, 24(3), 807-817.

Walker, J. M. ve Dotger, B. H. (2012). Because wisdom can't be told: using comparison of simulated parent-teacher conferences to assess teacher candidates' readiness for family-school partnership. Journal of Teacher Education, 63(1), 62-75.

Whyte, K. L. ve Karabon, A. (2016). Transforming teacher-family relationships: shifting roles and perceptions of home visits through the funds of knowledge approach. Early Years, 36(2), 207221.

Yakıc1, A. P. (2018). Okul öncesi velilerinin aile katılimm yordayan değişkenlerin incelenmesi. Yayımlanmamış Yüksek Lisans Tezi, Uşak Üniversitesi, Sosyal Bilimler Enstitüsü, Uşak.

Yaşar Ekici, F. (2017). Okul öncesi eğitim kurumlarındaki aile katılım çalışmalarına katılan ve katılmayan ailelerin çocuklarının sosyal beceri ve problem davranışları arasındaki ilişki. Hitit Üniversitesi Sosyal Bilimler Enstitüsü Dergisi, 10(1), 543-562. 
Yavuz Güler, Ç. (2014). Okul aile işbirliği: öğretmen adaylarını ailelerle çalışmaya yeterince hazırlayabiliyor muyuz?. Sosyal Bilimler Dergisi, 12(4), 72-90.

Yıldırım, A. ve Şimşek, H. (2013). Sosyal Bilimlerde Nitel Araştırma Yöntemleri. (9. Baskı) Ankara: Seçkin Yayıncılık. 